Антонова Антоніна Володимирівна, магістр психології, ПрАТ «ВНЗ «МАУП», 02000, вул. Фрометівська, 2, м. Київ, Україна

ORCID: 0000-0002-3849-155X

\title{
ПСИХОДІАГНОСТИКА РИЗИКУ БУЛІНГУ В ШКОЛІ
}

\begin{abstract}
Анотація
Ключові слова: школа, булінг, психодіагностика.

Постановка проблеми. За даними дослідження «UNICEF Україна» за 2017 рік, 67\% дітей зіштовхувалися з булінгом (були жертвою або свідком), а 40\% постраждалих від цькування взагалі ні з ким не ділилися проблемою і не зверталися за допомогою. Згідно з доповіддю Всесвітньої організації охорони здоров’я 2016 р., Україна посідає дев'яте місце серед 42 досліджуваних країн за відсотком жертв булінгу серед 15-річних. Тому дослідження проблеми шкільного булінгу з метою розробки ефективних способів його профілактики є важливим питанням психології.
\end{abstract}

Аналіз останніх досліджень i публікацій. скандинавськими дослідниками, зокрема, Д. Олвеус. П.П. Хайнеманн, А. Пікасо, Е. Роланд, було розроблено концепцію булінгу і визначено це поняття як утиск, дискримінацію, цькування. Булінг $є$ особливою формою деструктивної взаємодії, що включає в себе безліч специфічних типів і підтипів агресивної поведінки. На нашу думку найбільш структуроване і повно представлені форми булінгу в статті Є. Н. Ожійової «Булінг, як різновид насильства. Шкільний булінг».

Формулювання мети статті. Мета - визначити психологічні аспекти проблеми шкільного булінгу та виявлення його ризику.

Виклад основного матеріалу. Негативні прояви, маючи місце в обох класах, в 7-В за рядом показників перевищують такі в 7-Б класі майже вдвічі, що свідчить про підвищений ризик булінгу в цьому класі. Особливо 
значимими щодо ризику булінгу є зневажання, приниження один одного, насмішки, брутальний стиль розмови 3 нецензурними висловлюваннями, схильність до бійки та іï схвалення. Саме за цими параметрами в 7-Б класі виявилася більш ризикована ситуація щодо виникнення булінгу, ніж у 7-В. Серед способів булінгу перше місце посідають насмішки та ігнорування.

Також більшість учнів вказували, що вони не відчували ні психічного, ні фізичного насилля, але при цьому зазначали один або більше методів булінгу, які інші учні використовували до них. Це може пояснюватися тим, що це були поодинокі несистематичні випадки, що не є характерним для власне булінгу.

Висновки та перспективи подальших досліджень. Провідною проблемою діагностики та профілактики булінгу $\epsilon$ те, що в українській культурі даний феномен входить в звичайний досвід і мало усвідомлюється, в силу чого його прояви часто перериваються, a наслідки i ефекти залишаються поза фокусом уваги фахівців і учасників цькування.

Експериментальне дослідження 3 діагностики ризику булінгу в шкільному колективі показало наявність дітей - потенційних учасників цькування в кожному класі, що підтверджує актуальність даної теми.

Використані в нашому дослідженні психодіагностичні методики можуть застосовуватися для вирішення таких прикладних задач, як виявлення колективів $з$ підвищеним ризиком ситуацій цькування і створення безпечної атмосфери в навчальних групах, а також освітня і консультативна робота з вчителями і шкільною адміністрацією.

\section{Аннотация}

Антонова А. В., магистр психологии, ЧАО «ВУЗ «МАУП»; г. Киев, Украина. Психодиагностика риска буллинга в школе.

Ключевые слова: школа, буллинг, психодиагностика.

Постановка проблемы. По данным исследования «UNICEF Украины» по 2017, 67\% детей сталкивались с буллингом (были жертвой или 
свидетелем), а 40\% пострадавших от травли вообще ни с кем не делились проблемой и не обращались за помощью. Согласно докладу Всемирной организации здравоохранения 2016, Украина занимает девятое место среди 42 исследуемых стран по проценту жертв буллинга среди 15-летних. Поэтому исследование проблемы школьного буллинга с целью разработки эффективных способов его профилактики является важным вопросом психологии.

Анализ последних исследований и публикаций. Скандинавскими исследователями, в частности, Д. Олвеус. П.П. Хайнеманн, А. Пикассо, Э. Роланд, была разработана концепция буллинга и определено это понятие как ущемление, дискриминацию, травли. Буллинг является особой формой деструктивного взаимодействия, включает в себя множество специфических типов и подтипов агрессивного поведения. По нашему мнению наиболее структурированное и полно представлены формы буллинга в статье Е. Н. Ожиёвой «Буллинг, как разновидность насилия. Школьный буллинг».

Формулировка цели статьи. Цель - определить психологические аспекты проблемы школьного буллинга и выявления его риска.

Изложение основного материала. Негативные проявления, имея место в обоих классах, в 7-В по ряду показателей превышают таковые в 7-Б классе почти вдвое, что свидетельствует о повышенном риске буллинга в этом классе. Особенно значимыми в отношении риска буллинга является пренебрежение, унижение друг друга, насмешки, грубый стиль разговора с нецензурными выражениями, склонность к драке и ее одобрение. Именно по этим параметрам в 7-Б классе оказалась более рискованная ситуация относительно возникновения буллинга, чем в 7-В. Среди способов буллинга первое место занимают насмешки и игнорирования. Также большинство учеников указывали, что они не испытывали ни психического, ни физического насилия, но при этом отмечали один или более методов буллинг, другие ученики использовали к ним. Это может объясняться тем, 
что это были одиночные случаи, которые не имели систематического характера, характерного для собственно буллинга.

Выводы и перспективы дальнейших исследований. Ведущей проблемой диагностики и профилактики буллинга является то, что в украинской культуре данный феномен входит в обычный опыт и мало осознается, в силу чего его проявления часто прерываются, а последствия и эффекты остаются вне фокуса внимания специалистов и участников травли. Экспериментальное исследование по диагностике риска буллинга в школьном коллективе показало наличие детей - потенциальных участников травли в каждом классе, что подтверждает актуальность данной темы. Использованные в нашем исследовании психодиагностические методики могут применяться для решения таких прикладных задач, как выявление коллективов с повышенным риском ситуаций травли и создание безопасной атмосферы в учебных группах, а также образовательная и консультативная работа с учителями и школьной администрацией.

\section{Annotation}

Antonova A. V., Magister of Psychology, The Private Joint-Stock Company Higher Educational Institution Interregional Academy of Personnel Management; Kyiv, Ukraine. Psychodiagnosis of the risk of bullying at school.

Key words: school, bullying, psychodiagnostics.

Formulation of the problem. According to UNICEF Ukraine in 2017, 67\% of children were exposed to bullying (being a victim or a witness), and $40 \%$ of those affected by bullying did not share a problem with anyone at all and did not seek help. According to the report of the World Health Organization in 2016, Ukraine ranks ninth among the 42 surveyed countries by the percentage of 15 year-old bullying victims. Therefore, studying the problem of schoolbullyling in order to develop effective ways to prevent it is an important issue in psychology. Analysis of recent research and publications. Scandinavian researchers, in particular, D. Olveus. P.P. Heinemann, A. Picasso, E. Roland, the concept of 
boiling was developed and this concept is defined as oppression, discrimination, harassment. Booting is a special form of destructive interaction, which includes a lot of specific types and subtypes of aggressive behavior. In our opinion, the most structured and fully represented forms of a boom in the article by E. N. Ozhiev "Buling as a kind of violence. School bullyling ".

Formulating the purpose of the article. The aim is to determine the psychological aspects of the problem of schoolbullyling and to identify its risk.

Presenting main material. Negative manifestations, taking place in both classes, in the 7-B for a number of indicators exceed those in the 7-B class almost twice, indicating an increased risk of bolting in this class. Particularly significant in relation to the risk of bullyling are the humiliation, humiliation of one another, ridicule, the brutal style of conversation with obscene statements, propensity to fight and its approval. It is for these parameters that the 7-B class appeared to be more risky than the 7-B. Among the methods of bullying, the first place is ridiculed and ignored.

Also, most students indicated that they did not experience mental or physical violence, but noted one or more of the methods of bullying that other students used to them. This may be due to the fact that these were isolated unsystematic cases that are not typical for actual bullying.

Conclusions and perspectives of further research. The leading problem of diagnostics and prophylaxis of a boling is that in the Ukrainian culture this phenomenon is a common experience and little awareness, due to which its manifestations are often interrupted, and the consequences and effects remain beyond the focus of attention of experts and participants in the persecution. An experimental study on the diagnosis of the risk of bullying in the school team showed the presence of children - potential harassers in each class, which confirms the relevance of this topic.

The psychodiagnostic techniques used in our research can be used to solve such applied tasks, such as the identification of teams with increased risk of 
bullying situations and the creation of a safe atmosphere in the training groups, as well as educational and advisory work with teachers and school administration.

Ключові слова: школа, булінг, психодіагностика.

Постановка проблеми. За даними дослідження «UNICEF Україна» за 2017 рік, 67\% дітей зіштовхувалися з булінгом (були жертвою або свідком), а 40\% постраждалих від цькування взагалі ні з ким не ділилися проблемою і не зверталися за допомогою. Згідно з доповіддю Всесвітньої організації охорони здоров’я 2016 р., Україна посідає дев’яте місце серед 42 досліджуваних країн за відсотком жертв булінгу серед 15-річних. Судячи 3 усього, цькування розвивається майже в будь-якому закритому співтоваристві - будь то армійський підрозділ або елітний коледж, - i те, що діти регулярно стикаються з цькуванням в школі, лише приклад поширеності явища. Багато років працюючи над цією темою, в 1993 р. норвезький психолог Д. Ольвеус опублікував визначення цькування в середовищі дітей і підлітків, що стало загальноприйнятим: булінг (цькування) - це навмисна агресивна поведінка, що систематично повторюється та включає нерівність соціальної влади або фізичної сили (Olweus, 1993a). Його робота внесла явище булінгу в простір психологічної науки, зробила його видимим, і ця тема швидко стала трендом світової психології, дослідження в області феноменології і технологій профілактики та припинення булінгу стали стрімко розвиватися. Їх актуальність дуже висока в силу появи в учасників цькування важких наслідків, таких як суїцид. Тому дослідження проблеми шкільного булінгу 3 метою розробки ефективних способів його профілактики $\epsilon$ важливим питанням психології.

Аналіз останніх досліджень i публікацій. Вперше проблема шкільного насильства була описана ще на початку 20 століття - в 1905 році, коли К. Дьюкс опублікував про це своє дослідження, але по справжньому системне дослідження було проведено скандинавськими дослідниками, 
такими як Д. Олвеус. П.П. Хайнеманн, А. Пікасо, Е. Роланд [4]. Вони розробили концепцію булінгу i визначили це поняття як утиск, дискримінацію, цькування. В подальших дослідженнях цієї проблеми, різними дослідниками висувалися свої визначення цього явища, але всі вони відображали наявність великої групи соціальних, психологічних і педагогічних проблем, супроводжуючих фізичне, психічне насильство по відношенню до людини або групи людей, яке відрізняється тривалістю і нездатністю людини захиститися перед агресором. Виходячи з цього бачення проблеми, можна відзначити, що булінг не $є$ поведінкою в класичному розумінні, а являє собою особливу форму деструктивної взаємодії, що включає в себе безліч специфічних типів і підтипів агресивної поведінки [5].

Визначення булінгу як явища та основні підходи до цієї проблеми різних авторів представлені в таблиці 1. Зазначені характеристики дозволяють зрозуміти різницю між булінгом і випадковими конфліктами, бійкою або сваркою, які іноді відбуваються між людьми.

Потрібно відзначити, що хоча булінг в деякій мірі схожий за своєю структурою 3 конфліктом, проте, він відрізняється специфічними характеристиками: булінг розтягнутий в часі, сили жертви і кривдника асиметричні за своїм потенціалом, типи учасників булінгу фіксовані (кривдник, жертва, свідок, помічник буллі, захисник жертви), через що змінити роль дуже складно в такому типі поведінки. Крім того, є кардинальна відмінність конфлікту за своєю суттю від булінгу - в конфлікті обидві сторони так чи інакше можуть відстоювати свою позицію, залучаючи оточуючих як ресурс, тоді як в булінгу тільки одна сторона «володіє» правами, а іншій стороні «відмовляється в праві» взагалі мати якусь позицію і робити будь-які дії на свій захист [7].

Отже, булінг - це тип деструктивної поведінки, який містить в собі насильницькі дії кривдника по відношенню до жертви, яка нездатна себе захистити, і дії спрямовані на заподіяння шкоди жертві, протягом тривалого часу, для отримання психологічного або фізичного задоволення кривдником. 
При виникненні ситуації булінгу в групі - такий, як наприклад клас, створюється структура - соціальна система. I в цю структуру входять: агресори (переслідувачі), жертва, спостерігачі, і ця «система» здатна залучати інших людей [1].

Таблиця 1.1.

Основні підходи до визначення поняття «булінг» [4]

\begin{tabular}{|c|c|}
\hline Автор & Підходи до визначення боулінгу \\
\hline Роланд (1988) & Нападки будь-якого характеру \\
\hline Таттум (1989) & $\begin{array}{l}\text { Тривале фізичне або психологічне насильство } 3 \\
\text { боку індивіда або групи щодо індивіда, який не } \\
\text { здатний захистити себе в даній ситуації }\end{array}$ \\
\hline Безаг В. (1989) & $\begin{array}{l}\text { Неодноразовий напад - фізичний, психологічний, } \\
\text { соціальний або вербальний - тими, чия влада } \\
\text { формально або ситуативно вище, за тих, хто не має } \\
\text { можливості захиститися, } 3 \text { наміром заподіяти } \\
\text { страждання для досягнення власного задоволення }\end{array}$ \\
\hline Ольвеус Д. (1991) & $\begin{array}{l}\text { Особливий вид насильства, коли людина фізично } \\
\text { нападає або загрожує іншій людині, яка більш } \\
\text { слабка і безсила, для того щоб людина відчувала } \\
\text { себе наляканою, ізольованою, позбавленою свободи } \\
\text { дій тривалий час }\end{array}$ \\
\hline Хед (1994) & $\begin{array}{l}\text { Тривале насильство, фізичне або психологічне, } \\
\text { здійснюване однією людиною або групою і } \\
\text { спрямоване проти людини, яка не в змозі } \\
\text { захиститися у фактичній ситуації, з усвідомленим } \\
\text { бажанням заподіяти біль, налякати або піддати } \\
\text { людину тривалої напруги }\end{array}$ \\
\hline Хатьцер (1996) & $\begin{array}{l}\text { Деструктивна взаємодія, в якому домінуючий } \\
\text { суб'єкт неодноразово демонструє таку поведінку, } \\
\text { яке викликає замішання менш домінуючого } \\
\text { суб'єкта }\end{array}$ \\
\hline Кривцова С.В. (2011) & $\begin{array}{l}\text { Агресія одних дітей проти інших, коли мають місце } \\
\text { нерівність сил агресора і жертви, агресія має } \\
\text { тенденцію повторюватися. Нерівність сил, } \\
\text { повторюваність - дві істотні ознаки боулінгу }\end{array}$ \\
\hline
\end{tabular}

Деякі дослідники пропонують систематизувати всі прояви булінгу в дві групи: 1 група - прояви, пов'язані переважно 3 активними формами приниження; 2 група - прояви, пов'язані зі свідомою ізоляцією, обструкцією постраждалих [2]. 
На нашу думку найбільш структуроване і повно представлені форми булінгу в статті $€$. Н. Ожійової «Булінг, як різновид насильства. Шкільний булінг» [9]:

1. Фізичний булінг,- найбільш поширений серед хлопчиків. Вважається найжорстокішою формою булінгу, коли жертву б’ють, штовхають, ставлять підніжки, дають стусани під зад, а також побої, нанесені різними предметами.

2. Психологічний булінг,- цькування, пов'язане з дією на психіку, за допомогою вербальних образ, насмішок, залякувань, переслідувань, які здійснюють емоційний тиск на кривдника (жертву). До цієї форми відносяться: вербальний боулінг; образливі жести або дії; залякування; ізоляція; вимагання; пошкодження та інші дії з майном; кібербулінг.

У булінгу присутня певна структура, без неї не може відбутися феномен булінгу. Структура складається з трьох компонентів: буллер, жертва і глядачі. Буллі, як правило, виступають діти, що володіють нарцисичними рисами характеру [3]. В шкільному булінгу найчастіше бере участь ціла група дітей. Якщо лідер - буллі, то інші - послідовники ініціаторів цькування однокласників. Спостерігачі - це основна маса шкільного булінгу в класі. Спостерігачі булінгу часто відчувають страх і безпорадність перед буллі в школі. Їх може переслідувати почуття провини через те, що не відстоюють чужі інтереси, що не заступаються за дітей, яких принижують, через те, що вони підтримують кривдника. Почуття провини, що виникає, в них недовго присутне, поступово змінюються взаємовідносини в класі і норми, діти стають цинічними і безжальними до жертв. Подібне становище в класі робить процес протистояння булінгу в цьому класі більш складним і важко вирішуваним [6]. Шкільний булінг - явище системне і комплексне. Тому, крім шкільного психолога, подібними проблемами повинні займатися ще й вчителі, які зобов'язані припиняти ці ситуації, а не говорити, що діти самі повинні вирішувати подібні проблеми. 
Розглянемо фактори, що сприяють розвитку буллінгу в класі / школі. Їх можна розділити на індивідуальні та групові. До індивідуальних можуть бути віднесені: агресивність учнів (загострюється в період підліткової кризи особистості); попередній досвід життєдіяльності школярів, що включає в себе прояви власної агресивності і спостереження аналогічних проявів у найближчому оточенні - в сім'ї, в значній групі однолітків, в установах освіти, відвідуваних раніше; недостатній рівень розвитку комунікативних навичок, в тому числі відсутність прикладів і досвіду ненасильницьких взаємин і знань про свої права. Групові чинники: загальний психоемоційний фон установи освіти, що характеризується високим рівнем тривожності і психічної напруженості суб'єктів взаємодії в сукупності 3 невмінням контролювати власні емоції і регулювати стани; «політичну» систему установи освіти, що включає агресивні взаємовідносини всередині педагогічного колективу, в тому числі авторитарно-директивний стиль управління, відсутність обгрунтованої системи педагогічних і професійних вимог; особливості ставлення педагогів до школярів, побудовані на необгрунтованих вимогах з боку дорослих і максимальному безправ’ї дітей; система взаємовідносин всередині класного колективу; наявність загальновизнаних соціальних ролей, що включають ролі «жертви» i «господаря»; традиції в соціумі, пропаговані засобами масової інформації. [8].

Формулювання мети статті. Мета - визначити психологічні аспекти проблеми шкільного булінгу та виявлення його ризику.

Виклад основного матеріалу. В країнах Свропи і США існують кілька великих дослідницьких програм, які куруються урядами відповідних країн. Як інструмент виявлення використовуються спеціально структуровані опитувальники для самих дітей, вчителів та батьків.

В Україні досі не створено валідного практичного методу діагностики ризику булінгу, на результатах якого будувалася 6 ясна науковообгрунтована система профілактики. На практиці, в нашій країні більше 
орієнтуються на виявлення дітей і підлітків, які відносяться до групи ризику булінгу, і до останнього часу, одними 3 доступних методів діагностики булінгу були спостереження, бесіда, соціометричні дані. Профілактика булінгу можлива тільки при наявності ефективних діагностичних інструментів, що дозволяють оцінити ймовірність його виникнення в конкретному колективі.

Дослідження ризиків булінгу проводилося на базі Комунальної установи Сумської спеціалізованої школи І-ІІІ ступені № 2 ім. Д.Косаренко в м. Суми Сумської області, в дослідженні взяли участь 67 учнів 7-Б та 7-В класів (35 дівчаток, 32 хлопчики). Методи дослідження: теоретикоаналітичий, емпіричний, психодіагностичний, статистичний. Методики дослідження: Рівень згуртованості у класі (Карл Сішора); Опитувальник ризику булінгу за А. А. Бочавер, В. Б. Кузнєцової, Е. М. Біанкі, П. В. Дмитрівського, М. А. Завалишиної, Н. А. Капорской, К. Д. Хломова; Опитувальник «Ситуація булінгу в школі» В. Р. Петросянц.

Для аналізу ризиків булінгу в школі ми використовували декілька методик, що дозволило нам отримати не тільки детальну картину атмосфери в шкільних класах, але й зрозуміти, як пов'язані між собою емоційні зв'язки в класі, рівень згуртованості класу та фактична ситуація булінгу в класі.

Визначення рівня згуртованості учнівського колективу по Сішору. Порівняння рівня згуртованості учнів 7-Б та 7-В класів наведене в таблиці 2.

Таблиця 2.

Зведена порівняльна таблиця результатів дослідження рівня згуртованості учнів 7-Б і 7-В класів

\begin{tabular}{|c|c|c|c|c|c|}
\hline \multirow[t]{3}{*}{ Запитання } & \multicolumn{4}{|c|}{ Відповідь «ТАК» } & \multirow{3}{*}{\begin{tabular}{|c} 
t-критерій \\
Стьюдента \\
для \\
непов'язаних \\
сукупносей \\
при $\mathrm{f}=65$, \\
tкрит $=1,998$ \\
при $\alpha=0,05$
\end{tabular}} \\
\hline & \multicolumn{2}{|c|}{ 7-Б } & \multicolumn{2}{|c|}{ 7-B } & \\
\hline & $\begin{array}{l}\text { абс. } \\
\text { число }\end{array}$ & $\%$ & $\begin{array}{l}\text { абс. } \\
\text { числ } \\
\text { о } \\
\end{array}$ & $\%$ & \\
\hline \multicolumn{6}{|c|}{ І. Як би ви оцінили свою приналежність до класу? } \\
\hline $\begin{array}{l}\text { 1. Почуваю себе його членом, частиною } \\
\text { колективу. }\end{array}$ & 14 & 40,0 & 10 & 31,3 & 28,28 \\
\hline 2. Приймаю участь у більшості видів діяльності. & 10 & 28,5 & 8 & 25,0 & 14,14 \\
\hline
\end{tabular}




\begin{tabular}{|c|c|c|c|c|c|c|}
\hline \multicolumn{2}{|l|}{$\begin{array}{l}\text { 3. Приймаю участь в одних видах діяльності та не } \\
\text { приймаю участі в інших. }\end{array}$} & 8 & 22,9 & 3 & 9,4 & 35,36 \\
\hline \multicolumn{2}{|l|}{ 4. Не почуваю себе членом групи. } & 1 & 2,9 & 6 & 18,8 & 35,36 \\
\hline \multicolumn{2}{|l|}{ 5. Живу та існую окремо від неї. } & 0 & 0 & 0 & 0 & 0 \\
\hline \multicolumn{2}{|l|}{ 6. Не знаю, важко відповісти. } & 2 & 5,7 & 5 & 15,6 & 21,21 \\
\hline \multicolumn{2}{|l|}{ Всього } & 35 & 100 & 32 & 100 & \\
\hline \multicolumn{7}{|c|}{ II. Перейшли б ви до іншого класу, якби була така нагода (без зміни решти умов) } \\
\hline 1. Так, дуже хотів би перейти. & 0 & \multicolumn{2}{|c|}{$\mid$\begin{tabular}{l|l|} 
& 0 \\
\end{tabular}} & 3 & 9,4 & 21,21 \\
\hline 2. Скоріше перейшов би, ніж залишився. & 1 & \multicolumn{2}{|c|}{2,9} & 1 & 3,1 & 0,00 \\
\hline 3. Не бачу ніякої різниці. & 2 & \multicolumn{2}{|c|}{5,7} & 8 & 25,0 & 42,43 \\
\hline 4. Скоріш за все, залишився б у своєму класі. & 12 & \multicolumn{2}{|c|}{34,3} & 10 & 31,3 & 14,14 \\
\hline 5. Дуже хотів би залишитись у своєму класі. & 16 & \multicolumn{2}{|c|}{45,7} & 8 & 25,0 & 56,57 \\
\hline 6. Не знаю, важко відповісти. & 4 & \multicolumn{2}{|c|}{11,4} & 2 & 6,2 & 14,14 \\
\hline Всього & 35 & \multicolumn{2}{|c|}{100} & 32 & 100 & \\
\hline \multicolumn{7}{|c|}{ III. Які взаємини між членами вашого класу? } \\
\hline 1. Краще, ніж у більшості класів. & 2 & \multicolumn{2}{|c|}{$\mid$\begin{tabular}{l|l}
5,7 \\
\end{tabular}} & 2 & 6,2 & 0,00 \\
\hline 2. Приблизно такі ж, як і в більшості класів. & 20 & \multicolumn{2}{|c|}{57,1} & 18 & 56,3 & 14,14 \\
\hline 3. Не гірше, ніж у більшості класів. & 8 & \multicolumn{2}{|c|}{22,9} & 7 & 21,9 & 7,07 \\
\hline 4. Не знаю, важко відповісти. & 5 & \multicolumn{2}{|c|}{14,3} & 5 & 15,6 & 0,00 \\
\hline Всього & 35 & \multicolumn{2}{|c|}{100} & 32 & 100 & \\
\hline \multicolumn{6}{|c|}{ IV. Які у вас стосунки з учителями та адміністрацією школи? } & \\
\hline 1. Краще, ніж у більшості класів. & 5 & \multicolumn{2}{|c|}{14,3} & 3 & 9,4 & 14,14 \\
\hline 2. Приблизно такі ж, як і в більшості класів. & 13 & \multicolumn{2}{|c|}{37,1} & 14 & 43,8 & 7,07 \\
\hline 3. Не гірше, ніж у більшості класів. & 11 & \multicolumn{2}{|c|}{31,4} & 11 & 34,3 & 0,00 \\
\hline 4. Не знаю. & 6 & \multicolumn{2}{|c|}{17,2} & 4 & 12,5 & 14,14 \\
\hline Всього & 35 & \multicolumn{2}{|c|}{100} & 32 & 100 & \\
\hline V. Яке ставлення до навчання & зашо & му кл & aci? & & & \\
\hline 1. Краще, ніж у більшості класів. & 2 & &, 7 & 2 & 6,3 & 0,00 \\
\hline 2. Приблизно такі ж, як і в більшості класів. & 19 & & 4,3 & 16 & 50,0 & 21,21 \\
\hline 3. Не гірше, ніж у більшості класів. & 9 & & 5,7 & 10 & 31,3 & 7,07 \\
\hline 4. Не знаю. & 5 & & 4,3 & 4 & 12,5 & 7.07 \\
\hline Всього & 35 & & 00 & 32 & 100 & \\
\hline
\end{tabular}

Результати наших досліджень показали, що дівчата частіше беруть участь у спільних заходах (38,9\% проти 17,6\%), істотно більш позитивно оцінюють взаємини між членами класу (72,2\% проти 41,2\%) і частіше оцінюють ситуацію в класі як таку саму, як і в інших класах. В 7-Б класі, самосприйняття як члена колективу притаманне однаковій кількості дівчаток і хлопчиків (по 7 осіб, 38,9\% та 41,2\% відповідно), при тому що ці дівчатка беруть активну участь у більшості видів діяльності класу, а серед хлопчиків таких значно менше (38,9\% проти 17,6\%). Натомість, у 7-В класі членами колективу відчувають себе лише 35,5\% дівчаток і 26,7\% хлопчиків, i, так само як і в 7-Б класі, всі ці дівчатка беруть активну участь у всіх видах діяльності класу, тоді як таких хлопчиків у цьому класі істотно менше 
(13,3\%). В 7-Б класі членом групи не відчуває себе лише 1 хлопчик $(5,8 \%)$, тоді як у 7-В класі членами групи не відчувають себе 3 (17,6\%) дівчаток і 3 (20,0\%) хлопчиків. Біля половини учнів 7-Б класу не бажають переходити в інший клас, хочуть і надалі навчатися в своєму класі (38,9\% дівчаток і 52,9\% хлопчиків). Натомість, у 7-В класі таких лише 23,5\% дівчаток і 26,7\% хлопчиків, при цьому 20,0\% хлопчиків дуже бажають перейти в інший клас.

Грунтуючись на результатах тестування, можна відобразити їх для наочності в графічному вигляді (рис.1.-рис. 5.).

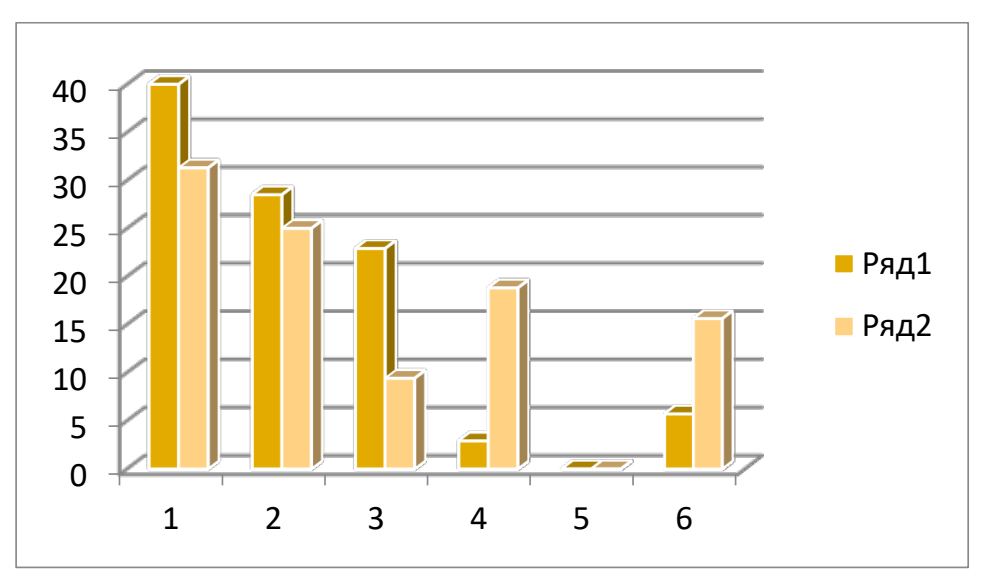

Рис. 1. Порівняння досліджуваних класів за параметром «Відчуття приналежності до класу» (ряд 1 - 7-Б клас, ряд 2 - 7-В клас; 1 - почуваю себе частиною колективу; 2 - приймаю участь у більшості видів діяльності; 3 - приймаю участь в одних видах діяльності та не приймаю участі в інших; 4 - не почуваю себе членом групи; 5 - живу та існую окремо від неї; 6 - не знаю, важко відповісти).

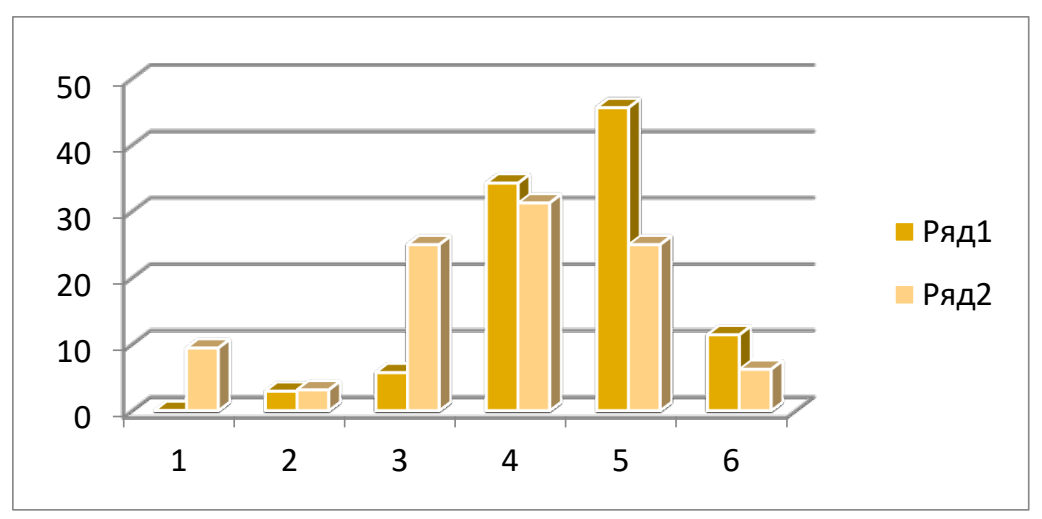

Рис. 2. Порівняння досліджуваних класів за параметром «Бажання перейти до іншого класу» (ряд 1 - 7-Б клас, ряд 2 - 7-В клас; 1 - так, дуже хотів би перейти; 2 скоріше перейшов би, ніж залишився; 3 - не бачу ніякої різниці; 4 - скоріш за все, залишився б у своєму класі; 5 - дуже хотів би залишитись у своєму класі; 6 - не знаю, важко відповісти). 


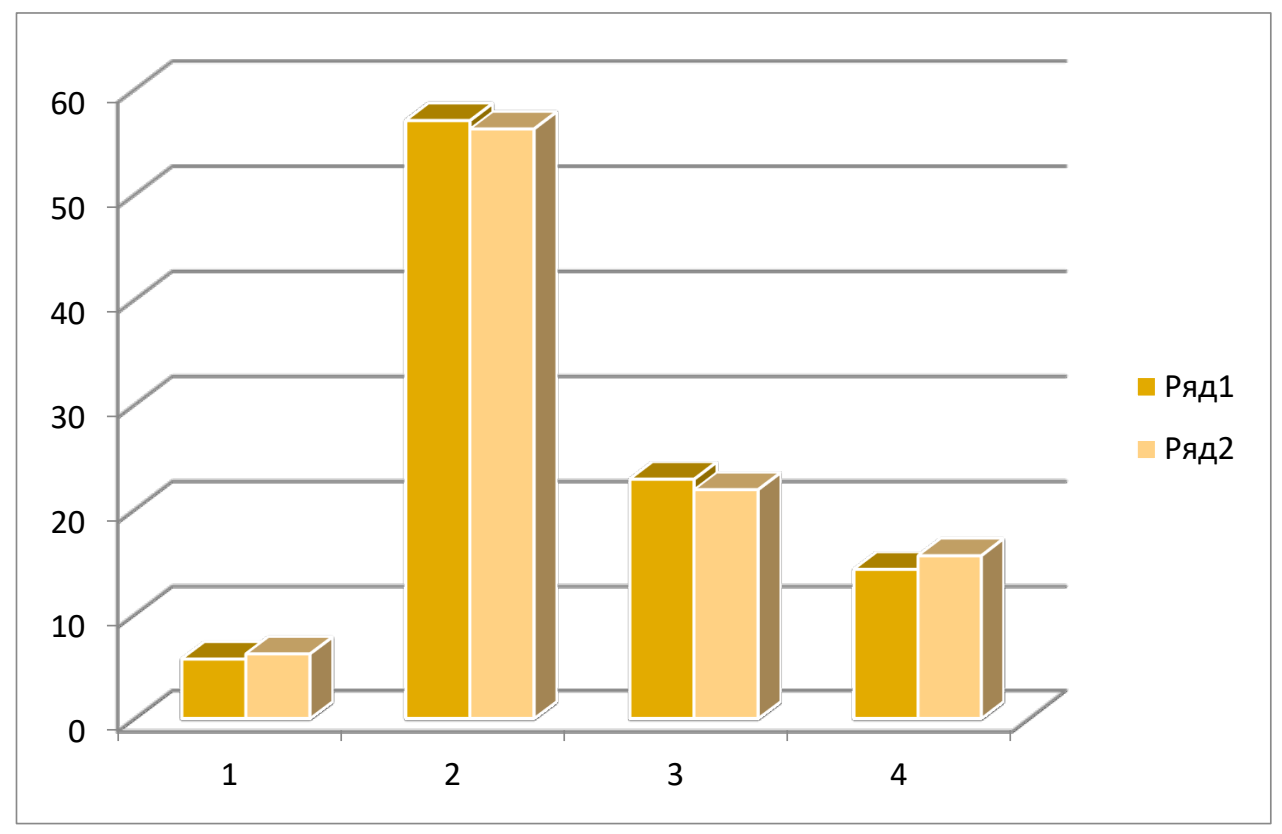

Рис. 3. Порівняння досліджуваних класів за параметром «Взаємини між членами класу» (ряд 1 - 7-Б клас, ряд 2 - 7-В клас; 1 - краще, ніж у більшості класів; 2 приблизно такі ж, як і в більшості класів; 3 - не гірше, ніж у більшості класів; 4 - не знаю, важко відповісти).

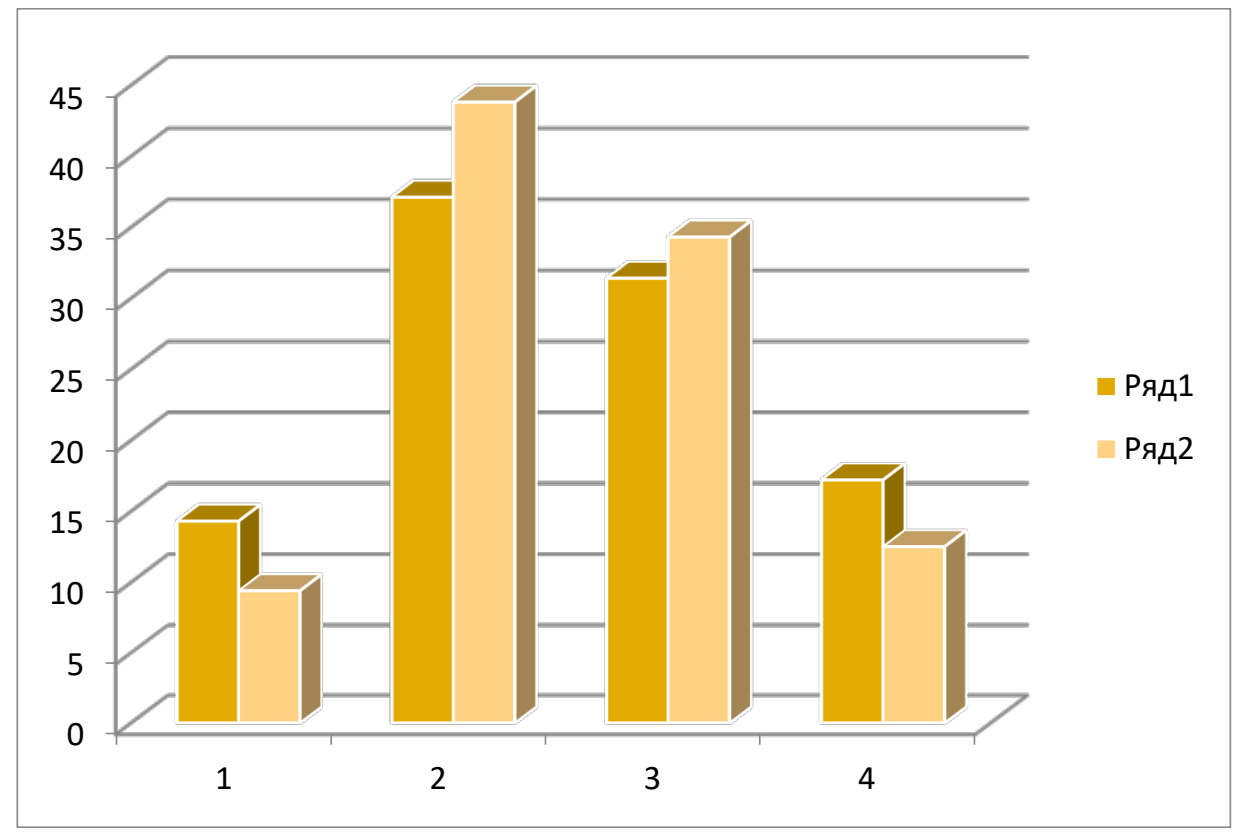

Рис. 4. Порівняння досліджуваних класів за параметром «Взаємини між учнями та вчителями (ряд 1 - 7-Б клас, ряд 2 - 7-В клас; 1 - краще, ніж у більшості класів; 2 - приблизно такі ж, як і в більшості класів; 3 - не гірше, ніж у більшості класів; 4 - не знаю, важко відповісти). 


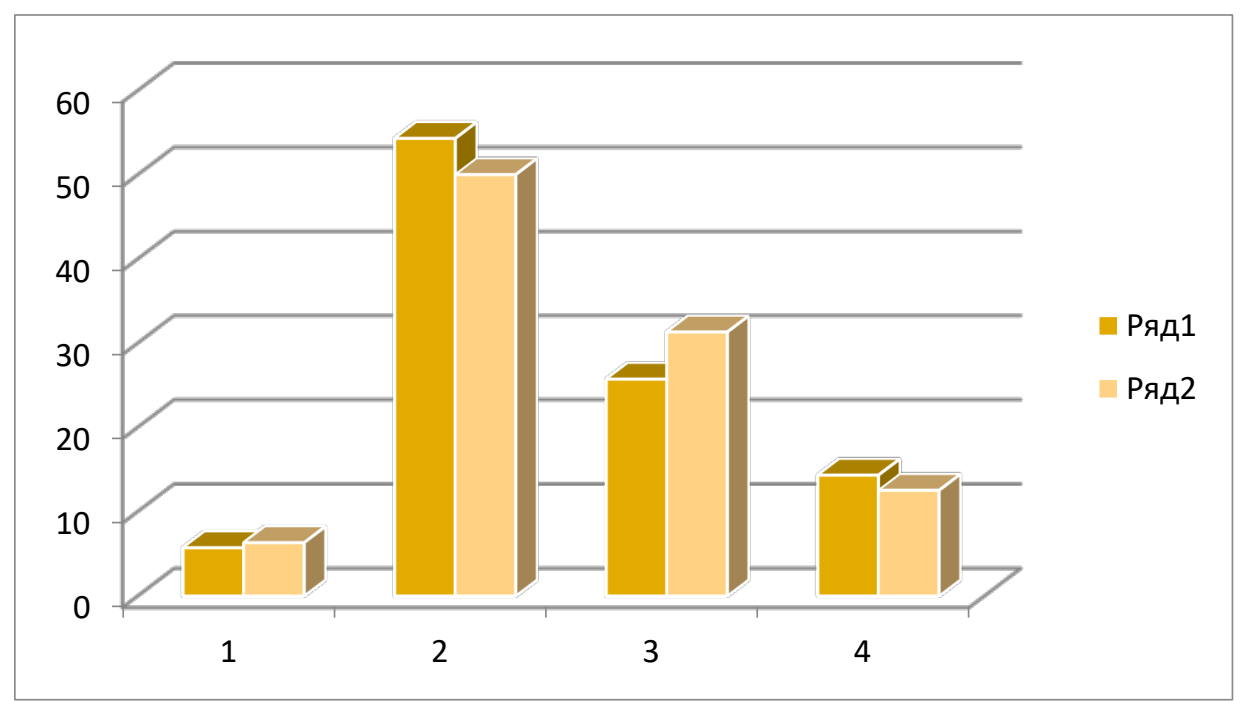

Рис. 5. Порівняння досліджуваних класів за параметром «Ставлення до навчання〉 (1 - 7-Б клас, 2 - 7-В клас; 1 - краще, ніж у більшості класів; 2 - приблизно такі ж, як і в більшості класів; 3 - не гірше, ніж у більшості класів; 4 - не знаю, важко відповісти).

Із рисунку 1. добре видно, що в 7-В класі, порівняно з 7-Б, менше дітей відчувають свою приналежність до класу, уникають участі в окремих видах діяльності, та значно більша кількість учнів не відчувають себе членами групи. Відповідно, в 7-В класі порівняно більше дітей не бажають надалі вчитися в своєму класі, висловлюють бажання перейти до іншого класу (рис.2.). За параметром «Взаємини між членами класу», як видно з рис. 3., істотної різниці між класами не виявлено, так само як і за параметром «Ставлення до навчання» (рис. 5.). Натомість, за параметром взаємин 3 учителями, ситуація в 7-В класі є більш помітною (рис. 4.).

За підрахунками індексу групової згуртованості Сішора, сума балів по 7-Б класу складає 479 балів, які потрібно розділити на кількість учнів, які були присутні на тестуванні, а це 35 учнів. Середній бал по класу 479/35=13,6 балів, що, згідно з інтерпретацією індексу групової згуртованості Сішора, вище середнього рівня згуртованості.

Сума балів по 7-В класу складає 352 бали, які потрібно розділити на кількість учнів, які були присутні на тестуванні, а це 32 учні. Середній бал по 
класу 352/32=11,0 балів, що, згідно 3 інтерпретацією індексу групової згуртованості Сішора, є середнім рівнем згуртованості (рис. 6.).

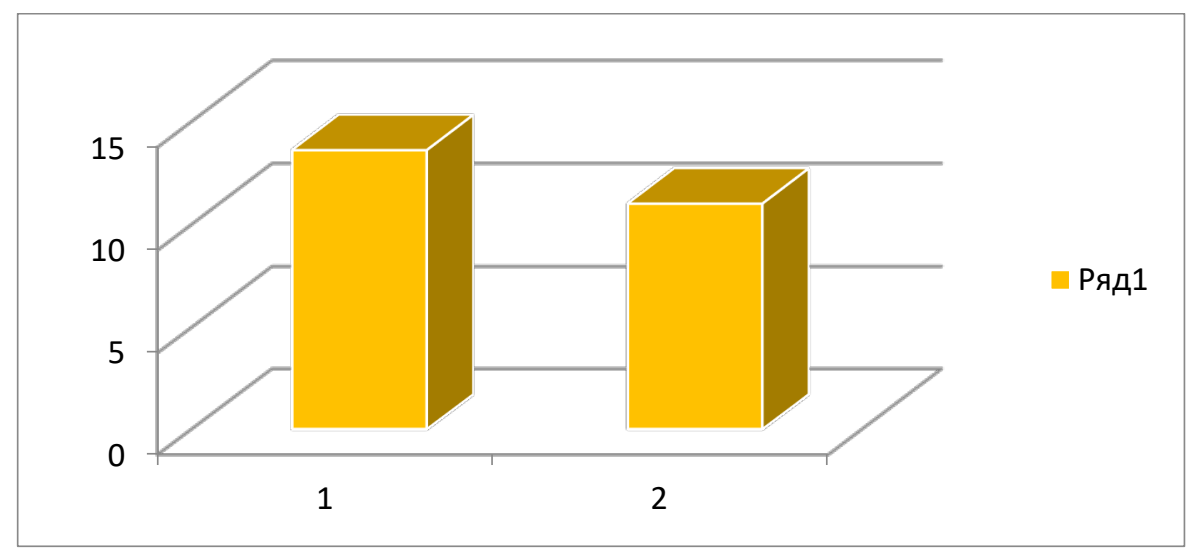

Рис. 6. Порівняння індексу згуртованості досліджуваних класів (1 - 7-Б клас, 2 - 7-В клас)

Отже, за результатами проведеного дослідження та відповідними розрахунками, в 7-Б класі індекс згуртованості класу вище середнього i дорівнює 13,6. Тільки один хлопець не почуває себе членом колективу, двоє дітей не знають, що відповісти на це питання. На питання, чи хотів би ти перейти до іншого класу, тільки одна дівчина відповіла, що скоріше би перейшла, двоє хлопців відповіли, що не бачать жодної різниці, і четверо дітей не знали, що відповісти на це запитання.

В 7-В класі рівень згуртованості нижчий, чим в 7-Б, та дорівнює 11 балів. На питання чи почуваєтесь ви членом колективу, шість дітей відповіли, що - ні, а п’ятеро не знали, що відповісти на це. Троє хлопців хотіли б перейти до іншого класу, одна дівчина відповіла, що скоріше б перейшла, ніж залишилась, вісім не бачать жодної різниці, а двоє дітей не знають, що відповісти. За результатами тестування було прийнято рішення провести соціометричний тест в 7-В класі, для того, щоб розібратися, які емоційні зв’язки в цьому класі і що можна зробити, щоб поліпшити атмосферу в класі, зробити їі більш дружньою та привітною.

Порівняльна оцінка ризику булінгу (ОРБ) за опитувальником А. А. Бочавер, В. Б. Кузнєцової, Е. М. Біанкі, П. В. Дмитрівського, М.А. Завалишиної, Н. А. Капорской, К. Д. Хломова представлено в таблиці 3. 
Таблиця 3.

Порівняльна оцінка ризику булінгу в досліджуваних класах

\begin{tabular}{|c|c|c|c|c|c|c|}
\hline \multirow[t]{2}{*}{ Запитання } & \multicolumn{2}{|l|}{ TAK } & \multirow{2}{*}{\begin{tabular}{|l}
$\mathrm{t}-$ \\
крит. \\
\end{tabular}} & \multicolumn{2}{|l|}{$\mathrm{HI}$} & \multirow{2}{*}{$\begin{array}{l}\text { t- } \\
\text { крит. }\end{array}$} \\
\hline & 7-Б & $7-\mathrm{B}$ & & $7-5$ & 7-B & \\
\hline $\begin{array}{l}\text { 1. У вашому класі прийнято:... } \\
\text { 1.1. заважати один одному, лізти, приставати? }\end{array}$ & 9 & 16 & 49,50 & 26 & 16 & 70,71 \\
\hline 1.2. разом розважатися після уроків; & 29 & 14 & 106,07 & 6 & 18 & 84,85 \\
\hline 1.3. жартувати над ким-небудь так, щоб сміявся весь клас; & 12 & 14 & 14,14 & 23 & 18 & 35,36 \\
\hline 1.4. битися; & 8 & 12 & 28,28 & 27 & 20 & 49,50 \\
\hline 1.5. ходити один до одного в гості; & 24 & 12 & 84,85 & 11 & 20 & 63,64 \\
\hline 1.6. заступатися за своїх; & 32 & 18 & 98,99 & 3 & 14 & 77,78 \\
\hline 1.7. обзиватися; & 7 & 11 & 28,28 & 28 & 21 & 49,50 \\
\hline 1.8. не заважати один одному займатися, чім захочеться. & 30 & 21 & 63,64 & 5 & 11 & 42,43 \\
\hline $\begin{array}{l}\text { 2. У вашому класі є хтось: } \\
\text { 2.1. кого всі поважають; }\end{array}$ & 27 & 18 & 63,64 & 8 & 14 & 42,43 \\
\hline 2.2. кого всі бояться; & 7 & 12 & 35,36 & 28 & 20 & 56,57 \\
\hline 2.3. над ким всі сміються; & 6 & 13 & 49,50 & 29 & 19 & 70,71 \\
\hline 2.4. ким часто незадоволені вчителі; & 31 & 30 & 7,07 & 4 & 2 & 14,14 \\
\hline 2.5. на кого хочеться бути схожим; & 16 & 10 & 42,43 & 18 & 22 & 28,28 \\
\hline 2.6. 3 ким краще не сперечатися; & 14 & 17 & 21,21 & 21 & 15 & 42,43 \\
\hline 2.7. хто ніколи не прогулює; & 31 & 21 & 70,71 & 4 & 11 & 49,50 \\
\hline 2.8. з ким навіть вчитель не може впоратися. & 32 & 30 & 14,14 & 3 & 2 & 7,07 \\
\hline $\begin{array}{l}\text { 3. Як до вас в класі звертаються зазвичай вчителя? } \\
\text { 3.1. по імені; }\end{array}$ & 32 & 27 & 35,36 & 3 & 5 & 14,14 \\
\hline 3.2. по імені та по батькові; & 5 & 4 & 7,07 & 30 & 28 & 14,14 \\
\hline 3.3. на прізвище; & 32 & 30 & 14,14 & 3 & 2 & 7,07 \\
\hline 3.4. на прізвиська. & 2 & 2 & 0,00 & 33 & 30 & 21,21 \\
\hline $\begin{array}{l}\text { 4. Коли в школі відбувається бійка, ви ... } \\
\text { 4.1. дивуєтеся; }\end{array}$ & 15 & 7 & 56,57 & 20 & 26 & 42,43 \\
\hline 4.2. не звертаєте уваги, це звичайна справа; & 9 & 22 & 91,92 & 26 & 10 & 113,14 \\
\hline 4.3. приєднуєтеся, вставши на чиюсь сторону; & 5 & 2 & 21,21 & 30 & 33 & 21,21 \\
\hline 4.4. багато це потім обговорюєте між собою в класі. & 23 & 13 & 70,71 & 12 & 19 & 49,50 \\
\hline $\begin{array}{l}\text { 5. Цінні речі ... } \\
\text { 5.1. намагаюся не носити в школу взагалі; }\end{array}$ & 13 & 16 & 21,21 & 22 & 16 & 42,43 \\
\hline 5.2. спокійно залишаю в класі; & 12 & 12 & 0,00 & 23 & 20 & 21,21 \\
\hline 5.3. можна залишити в коридорі; & 3 & 3 & 0,00 & 32 & 29 & 21,21 \\
\hline 5.4. був випадок, що вкрали; & 20 & 21 & 7,07 & 15 & 11 & 28,28 \\
\hline 5.5. залишаю в роздягальні. & 11 & 6 & 35,36 & 24 & 26 & 14,14 \\
\hline $\begin{array}{l}\text { 6. Виклик до директора - це ... } \\
\text { хочуть за щось похвалити; }\end{array}$ & 21 & 11 & 70,71 & 14 & 21 & 49.50 \\
\hline $\begin{array}{l}\text { 7. У вашій школі мат, лайки ... } \\
\text { 7.1.; звучать на перервах в особистих розмовах }\end{array}$ & 23 & 27 & 28,28 & 12 & 5 & 49,500 \\
\hline 7.2. не прийняті взагалі. & 15 & 5 & 70,71 & 20 & 27 & 49,50 \\
\hline $\begin{array}{l}\text { 8. У вашій школі ... } \\
\text { курять в туалетах, під сходами. }\end{array}$ & 2 & 2 & 0,00 & 33 & 30 & 21,21 \\
\hline $\begin{array}{l}\text { 9. У вашій школі стіни, меблі ... } \\
\text { списані, забруднені. }\end{array}$ & 8 & 8 & 0,00 & 27 & 24 & 21,21 \\
\hline $\begin{array}{l}\text { 10. Якщо хтось починає кричати, або битися, або клас «встає на } \\
\text { вуха», що потрібно, щоб це припинилося: } \\
\text { 10.1. хтось із учнів повинен сказати «досить»; }\end{array}$ & 27 & 16 & 77,78 & 8 & 16 & 56,57 \\
\hline 10.2. повинен прийти директор; & 20 & 24 & 28,28 & 15 & 8 & 49,50 \\
\hline 10.3. це припиниться, коли всі втомляться. & 10 & 15 & 35,36 & 25 & 17 & 56,57 \\
\hline $\begin{array}{l}\text { 11. У школі вам ... } \\
\text { 11.1. в цілому подобається, приємно, цікаво. }\end{array}$ & 35 & 22 & 91,92 & 0 & 10 & 70,71 \\
\hline 11.2. в цілому не подобається, погано, ніхто ні з ким не дружить. & 0 & 10 & 70,71 & 35 & 22 & 91,92 \\
\hline 12. Перерву я проводжу, заходячи к друзям в інші класи & 10 & 8 & 14,14 & 25 & 24 & 7,07 \\
\hline $\begin{array}{l}\text { 13. Коли ваш клас їде кудись з вчителями: } \\
\text { 13.1. це звичайна ситуація; }\end{array}$ & 20 & 16 & 28,28 & 15 & 16 & 7,07 \\
\hline 13.2. вам це подобається, це весело; & 33 & 20 & 91,92 & 2 & 12 & 70,71 \\
\hline 13.3. ви намагаєтеся не їздити; & 2 & 9 & 46,50 & 33 & 23 & 70,71 \\
\hline 13.4. учителям це складно, вони кожен кажуть, що це «в останній раз». & 8 & 13 & 35,36 & 27 & 19 & 56,57 \\
\hline $\begin{array}{l}\text { 14. Ваш клас має репутацію: } \\
\text { 14.1. відмінників; }\end{array}$ & 6 & 5 & 7,07 & 29 & 27 & 14,14 \\
\hline 14.2. хуліганів; & 10 & 15 & 35,36 & 25 & 17 & 56,57 \\
\hline 14.3. звичайнісінького, нічим не відрізняється від інших класів в & 32 & 21 & 77,78 & 3 & 11 & 56 \\
\hline 14.4. класу, в якому ніхто не хоче бути класним керівником. & 2 & 33 & 219,20 & 1 & 16 & 106,07 \\
\hline
\end{tabular}


Як видно з наведеної таблиці, показники ризику булінгу в 7-В класі статистично значимо відрізняються від таких у 7-Б класі.

Шкала небезпеки вимірює ступінь нормалізації неповаги, небезпеки i нехтування правилами і кордонами. Високі показники за цією шкалою говорять про посилення суб’ єктивного відчуття небезпеки у учасників групи і підвищений ризик різних дезадаптивних способів впоратися 3 тривогою, в тому числі з цькуванням, інших форм агресивної поведінки. До шкали небезпеки входять 16 питань опитувальника (максимальна кількість балів 16), за кожну позитивну відповідь на 12 з цих питань зараховується бал, та за кожну негативну відповідь на 4 інших питання також зараховується бал (таб.4- а, б; рис. 7.- а,б).

Таблиця 4.

Порівняння досліджуваних класів за шкалою небезпеки булінгу

\begin{tabular}{|c|c|c|c|c|c|c|c|}
\hline \multirow{2}{*}{$\begin{array}{l}\text { № } \\
3 / \Pi\end{array}$} & \multirow{2}{*}{ Запитання } & \multicolumn{2}{|l|}{$\begin{array}{l}7-6 \\
\end{array}$} & \multicolumn{2}{|l|}{$7-B$} & \multirow[b]{2}{*}{$\begin{array}{l}\text { t-критерій } \\
\text { Стьюдента } \\
\text { для } \\
\text { непов'язаних } \\
\text { сукупностей }\end{array}$} & \multirow{2}{*}{$\begin{array}{l}\text { Відношення } \\
\text { шансів } \\
\text { (OR) }\end{array}$} \\
\hline & & $\begin{array}{c}\text { абс. } \\
\text { число }\end{array}$ & $\%$ & $\begin{array}{l}\text { абб. } \\
\text { число }\end{array}$ & $\%$ & & \\
\hline \multicolumn{8}{|c|}{$\mathrm{A}$} \\
\hline 1. & $\begin{array}{l}\text { В класі прийнято заважати один } \\
\text { одному, лізти, приставати }\end{array}$ & 9 & 25,7 & 16 & 50,0 & 49,50 & 2,889 \\
\hline 2. & $\begin{array}{l}\text { В класі прийнято жартувати над } \\
\text { ким-небудь так, щоб сміявся } \\
\text { весь клас }\end{array}$ & 12 & 34,3 & 14 & 43,8 & 14,14 & 1,491 \\
\hline 3. & В класі прийнято обзиватися & 7 & 20,0 & 11 & 34,4 & 28,28 & 2,095 \\
\hline 4. & $\begin{array}{l}\text { У класі } є \text { хтось над ким всі } \\
\text { сміються }\end{array}$ & 6 & 17,1 & 13 & 40,6 & 49,50 & 3,307 \\
\hline 5. & $\begin{array}{l}\text { У класі є хтось ким часто } \\
\text { незадоволені вчителі }\end{array}$ & 31 & 88,6 & 30 & 93,8 & 7,07 & 1,935 \\
\hline 6. & $\begin{array}{l}\text { У класі є хтось } 3 \text { ким навіть } \\
\text { учитель не може впоратися }\end{array}$ & 32 & 91,4 & 30 & 93,8 & 14,14 & 1,406 \\
\hline 7. & $\begin{array}{l}\text { Вчитель в класі звертається до } \\
\text { учнів на прізвиська }\end{array}$ & 2 & 5,7 & 2 & 6,25 & 0,00 & 1,100 \\
\hline 8. & $\begin{array}{l}\text { Мат, лайки в школі звучать на } \\
\text { перервах в особистих розмовах }\end{array}$ & 23 & 65,7 & 27 & 84,4 & 28,28 & 2,817 \\
\hline 9. & $\begin{array}{l}\text { В школі курять під сходами, в } \\
\text { туалетах }\end{array}$ & 2 & 5,8 & 2 & 6,25 & 0,00 & 1,100 \\
\hline 10 . & $\begin{array}{l}\text { В школі парти та стіни брудні } \\
\text { та списані }\end{array}$ & 8 & 33,9 & 8 & 25,0 & 0,00 & 1,208 \\
\hline 11. & $\begin{array}{l}\text { Якщо клас «встає на вуха», щоб } \\
\text { припинити це, повинен прийти } \\
\text { директор }\end{array}$ & 20 & 57,1 & 24 & 75,0 & 28,28 & 2,250 \\
\hline
\end{tabular}




\begin{tabular}{|c|c|c|c|c|c|c|c|}
\hline No & Запитання & \multicolumn{2}{|l|}{ 7-Б } & \multicolumn{2}{|l|}{ 7-B } & t-критерій & \multirow{2}{*}{$\begin{array}{c}\text { Відношення } \\
2,206\end{array}$} \\
\hline 12. & Клас має репутацію хуліганів & 10 & 28,6 & 15 & 46,9 & 35,36 & \\
\hline \multicolumn{7}{|c|}{$\overline{5}$} & \\
\hline 13. & $\begin{array}{l}\text { В класі прийнято не заважати } \\
\text { один одному займатися, чім } \\
\text { захочеться }\end{array}$ & 5 & 14,3 & 11 & 34,4 & 42,43 & 3,141 \\
\hline 14. & $\begin{array}{l}\text { Коли в школі відбувається } \\
\text { бійка, ви дивуєтеся }\end{array}$ & 7 & 20,0 & 26 & 81,3 & 134,35 & 17,333 \\
\hline 15. & $\begin{array}{l}\text { Мат, лайка в школі не прийнята } \\
\text { взагалі }\end{array}$ & 5 & 14,3 & 20 & 62,5 & 106,07 & 10,000 \\
\hline 16. & $\begin{array}{l}\text { Якщо клас «встає на вуха», щоб } \\
\text { припинити це, хтось } 3 \text { учнів } \\
\text { повинен сказати «досить» }\end{array}$ & 16 & 45,7 & 16 & 50,0 & 0,00 & 1,188 \\
\hline
\end{tabular}

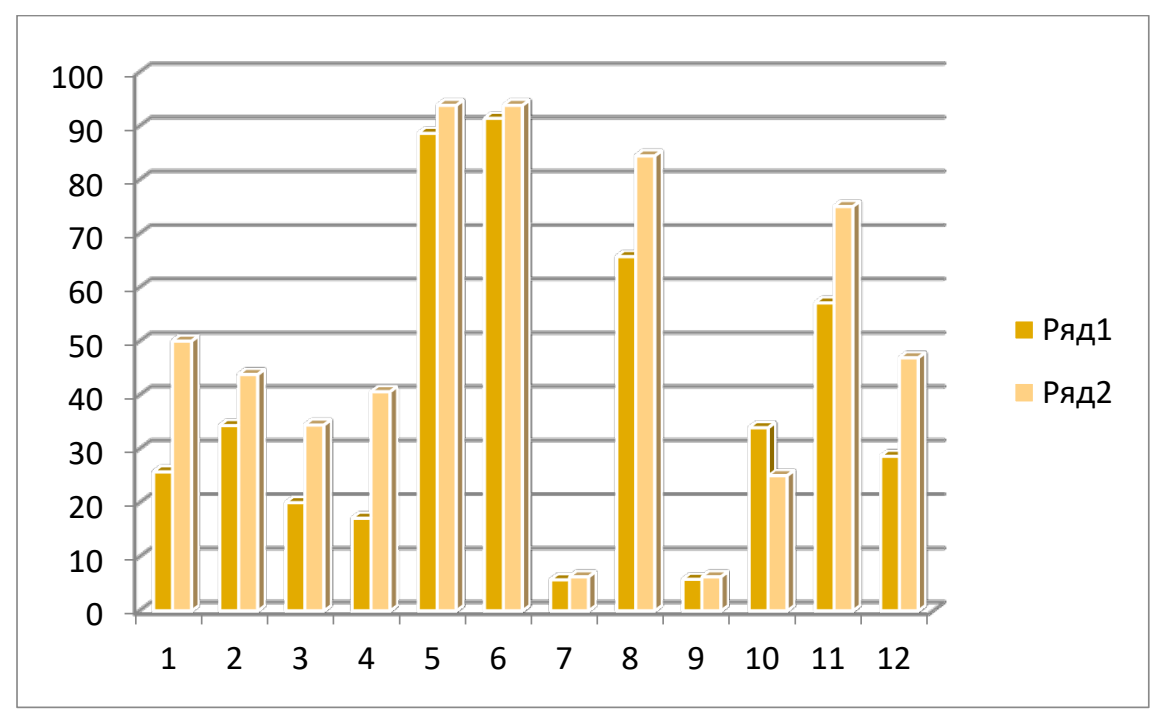

a

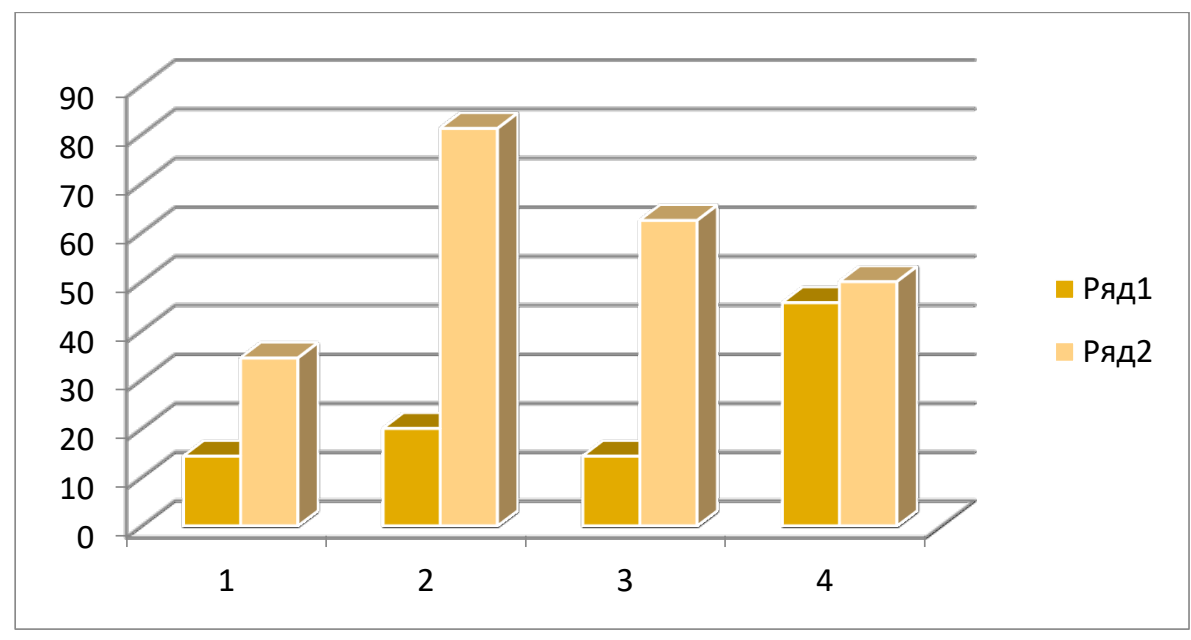

6

Рис.7. Порівняння класів за шкалою небезпеки булінгу (а - відповіді «ТАК», б - відповіді «НІ»; ряд 1 - 7-Б, ряд 2 - 7-В класи) 
Як видно з таблиці та наочно представлено на рисунку, в 7-В класі за більшістю питань даної шкали показники булінгу істотно відрізняються від таких в 7-Б класі. В 7-Б класі майже половина опитаних дітей вказали, що обзивання, насмішки та приставання є фактично звичайною поведінкою та манерою спілкування в даному колективі, при цьому вчителі недостатньо володіють ситуацією, висловлюють своє незадоволення - і при цьому не можуть впоратися з деякими учнями, на що сказали 93,8\% опитаних 7-В класу. В 7-Б класі за такими показниками ситуація теж не є втішною, ствердно відповіли на запитання шкали про незадоволення та безпорадність учителів від 91,4\% до 88,6\% учнів 7-Б класу. Однак приставання, насмішки та обзивання зустрічаються в 7-Б класі майже вдвічі рідше, ніж у 7-В класі.

Звертає увагу той прикрий факт, що в обох класах на перервах і в особистих розмовах учні вживають лайку, нецензурну мову, на що вказали $65,7 \%$ учнів 7-Б та аж 84,4 \% учнів 7-В класів. Понад чверть учнів зазначили, що в класах парти і стіни брудні та списані, що віддзеркалює негативне ставлення учнів загалом до навчання, шкільної обстановки, невдоволення ситуацією, і цей спротив, при нездатності вирішити проблемні питання, виявляється в псуванні шкільного майна. Отже, цілком логічно випливають відповіді чверті учнів 7-Б та половини учнів 7-В класу про те, що клас має репутацію хуліганів.

Отже, в обох класах спілкування між учнями містить брутальний, зневажливий характер, вчителі невдоволені та безпорадні, вплинути на поведінку учнів може хіба що директор школи, при тому що даних про наявність конкретних неформальних лідерів у класах не виявлено. Стіни й парти в класах брудні списані. Тобто, ні психологічна, ні зовнішня обстановка не заохочує до навчання.

Однак негативні прояви, маючи місце в обох класах, в 7-В за рядом показників перевищують такі в 7-Б класі майже вдвічі, що свідчить про підвищений ризик булінгу в цьому класі. Порівняння 7-Б та 7-В класів за шансами виникнення булінгу по кожному з 16 показників шкали, показало 
наявність істотних взаємозв'язків можливості булінгу 3 відповідними факторами, тому що показник OR за всіма показниками шкали перевищив 1, знаходячись за межами довірчого інтервалу. Особливо значимими щодо ризику булінгу $є$ зневажання, приниження один одного, насмішки, брутальний стиль розмови $з$ нецензурними висловлюваннями, схильність до бійки та їі схвалення. Саме за цими параметрами в 7-Б класі виявилася більш ризикована ситуація щодо виникнення булінгу, ніж у 7-В.

Шкала благополуччя характеризує стійкість кордонів, дотримання правил і утвердження поваги як норми в групі. Високі показники за цією шкалою вказують на реалізацію цінності поваги, яка представляє собою якісну альтернативу цінності влади і сили і служить фактором захисту від ризику розвитку ситуацій булінгу.

До шкали благополуччя входять 11 питань опитувальника (максимальна кількість балів 11), за кожну позитивну відповідь на 6 із цих питань зараховується бал, та за кожну негативну відповідь на 5 інших питань також зараховується бал (таблиця 5. а, б; рис. 8. а, б).

Як бачимо, за більшістю показників даної шкали між досліджуваними класами є статистично значима різниця, причому 7-В клас виявляється менш благополучним у порівнянні з 7-Б класом, хоча в цілому обидва класи за цією методикою виявилися відносно благополучними. При цьому, шанси розвитку булінгу, як показує ця методика, в значній мірі залежать від учителів, висловлювання якими невдоволення учнями істотно збільшує ризик булінгу.

Шкала роз’єднаності спрямована на оцінку відсутності згуртованості, величини дистанції між підлітками, а також між ними і вчителями, пов'язаними 3 відсутністю інструментів впливу друг на друга. Високі показники характеризують неконтрольованість групи i вибір стратегії уникнення контактів серед учасників в силу відсутності підтримки i можливості діалогу. Це не обумовлює булінг безпосередньо, проте при розвитку ситуації цькування знижує ймовірність його припинення, оскільки в групі відсутні взаємовиручка і підтримка. 
Таблиця 5.

Порівняння досліджуваних класів за шкалою благополуччя

\begin{tabular}{|c|c|c|c|c|c|c|c|}
\hline \multirow[t]{2}{*}{ № 3/ா } & \multirow[t]{2}{*}{ Запитання } & \multicolumn{2}{|l|}{ 7-Б } & \multicolumn{2}{|l|}{ 7-B } & \multirow{2}{*}{$\begin{array}{l}\text { t-критерій } \\
\text { Стьюдента } \\
\text { для } \\
\text { непов'язаних } \\
\text { сукупностей }\end{array}$} & \multirow{2}{*}{$\begin{array}{l}\text { Відношення } \\
\text { шансів } \\
\text { (OR) }\end{array}$} \\
\hline & & $\begin{array}{c}\text { абс. } \\
\text { число }\end{array}$ & $\%$ & $\begin{array}{c}\text { абс. } \\
\text { число }\end{array}$ & $\%$ & & \\
\hline \multicolumn{8}{|c|}{ A } \\
\hline 1. & $\begin{array}{l}\text { У класі є хтось хто ніколи } \\
\text { не прогулює }\end{array}$ & 31 & 88,6 & 21 & 65,6 & 70,71 & 0,246 \\
\hline 2. & $\begin{array}{l}\text { Вчитель в класі } \\
\text { звертається до учнів по } \\
\text { імені }\end{array}$ & 32 & 91,4 & 27 & 84,4 & 35,36 & 0,506 \\
\hline 3. & $\begin{array}{l}\text { Цінні речі можна } \\
\text { спокійно залишати в класі }\end{array}$ & 12 & 34,38 , & 12 & 37,5 & 0,00 & 1,150 \\
\hline 4. & $\begin{array}{l}\text { Цінні речі можна } \\
\text { залишати в коридорі }\end{array}$ & 3 & 8,6 & 3 & 9,4 & 0,00 & 1,103 \\
\hline 5. & $\begin{array}{l}\text { Коли ваш клас їде кудись } \\
\text { з вчителями це звичайна } \\
\text { ситуація }\end{array}$ & 20 & 57,1 & 16 & 50,0 & 28,28 & 0,750 \\
\hline 6. & $\begin{array}{l}\text { Клас має репутацію } \\
\text { звичайнісінького, нічим } \\
\text { не відрізняється від інших } \\
\text { класів в школі } \\
\end{array}$ & 32 & 91,4 & 21 & 65,6 & 77.78 & 0,172 \\
\hline \multicolumn{8}{|c|}{ Б } \\
\hline 7. & $\begin{array}{l}\text { Вчитель в класі } \\
\text { звертається до учнів на } \\
\text { прізвище }\end{array}$ & 3 & 8,5 & 2 & 6,25 & 7,07 & 0,711 \\
\hline 8. & $\begin{array}{l}\text { Цінні речі намагаюся в } \\
\text { школу не носити взагалі }\end{array}$ & 22 & 62,9 & 16 & 50,0 & 42,43 & 0,591 \\
\hline 9. & $\begin{array}{l}\text { Був випадок, що вкрали } \\
\text { цінні речі }\end{array}$ & 15 & 42,9 & 11 & 34,4 & 28,28 & 1,925 \\
\hline 10. & $\begin{array}{l}\text { Коли ваш клас їде кудись } \\
\text { учителям це складно, } \\
\text { вони кожен раз кажуть, } \\
\text { що «це в останній раз» }\end{array}$ & 27 & 77,1 & 19 & 59,4 & 56,57 & 0,433 \\
\hline 11. & $\begin{array}{l}\text { Клас має репутацію, в } \\
\text { якому ніхто не хоче бути } \\
\text { класним керівником }\end{array}$ & 1 & 2,89 & 16 & 50,0 & 106,107 & 34,000 \\
\hline
\end{tabular}




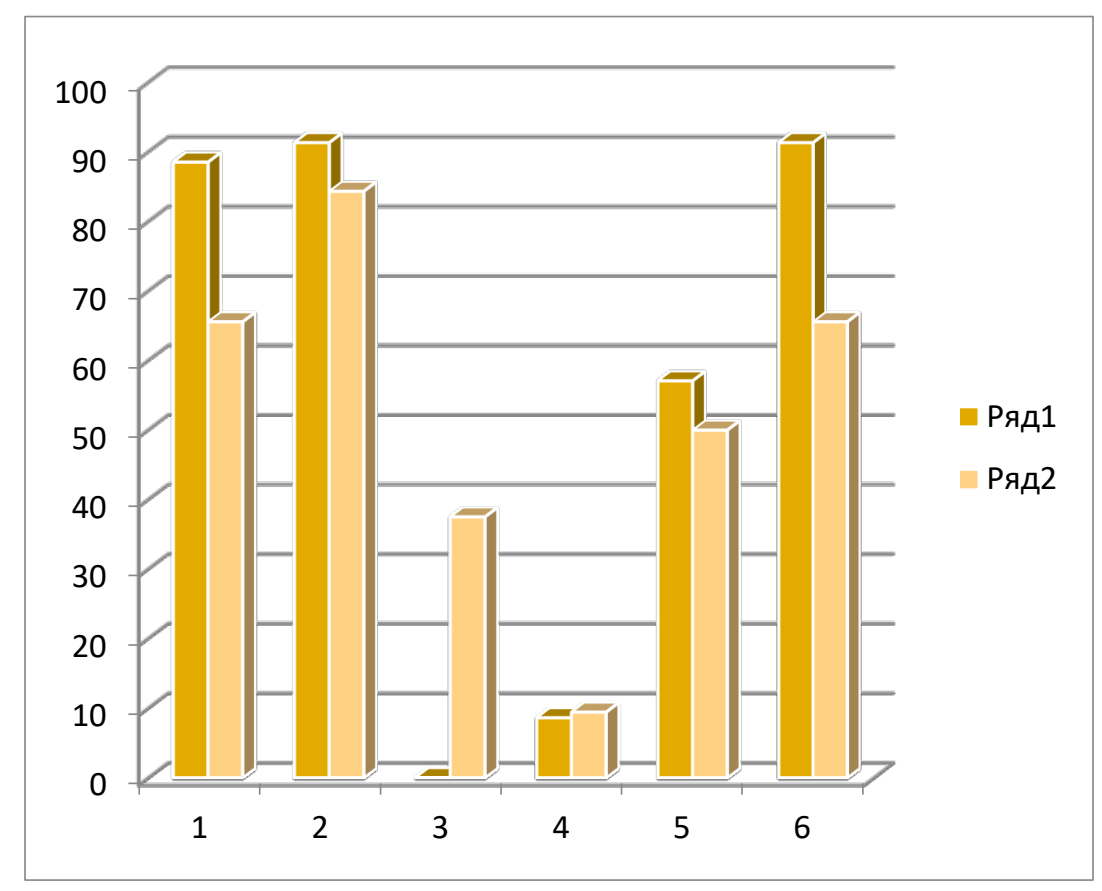

a

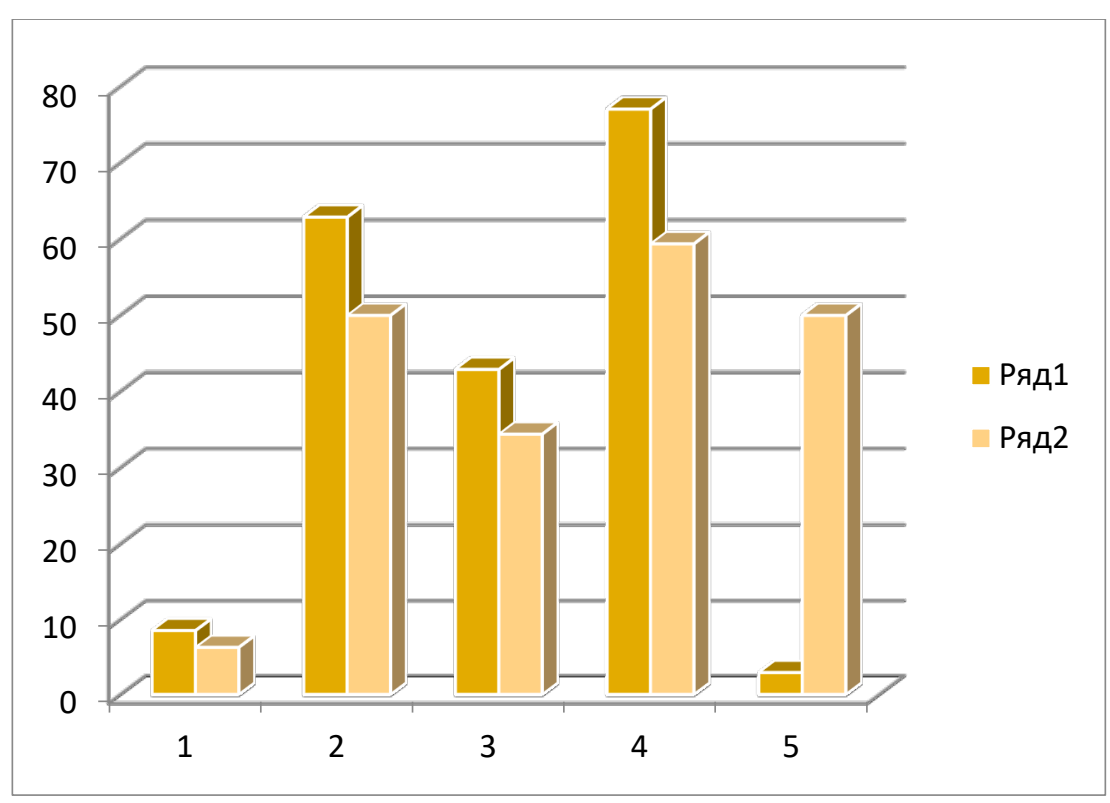

6

Рис.8. Порівняння класів за шкалою благополуччя щодо булінгу (а відповіді «ТАК», б - відповіді «НІ»; ряд 1 - 7-Б, ряд 2 - 7-В класи)

До шкали роз'єднаності входять 10 питань (максимальна кількість балів 10), за кожну позитивну відповідь на 5 з цих питань зараховується бал, та за кожну негативну відповідь на 5 інших питань також зараховується бал (таблиця 6 a, б; рис.9. а, б). 
Таблиця 6.

Порівняння досліджуваних класів за шкалою роз'єднаності

\begin{tabular}{|c|c|c|c|c|c|c|c|}
\hline \multirow{2}{*}{$\begin{array}{l}\text { № } \\
\text { 3/ח }\end{array}$} & \multirow[t]{2}{*}{ Запитання } & \multicolumn{2}{|l|}{ 7-Б } & \multicolumn{2}{|l|}{ 7-B } & \multirow{2}{*}{$\begin{array}{l}\text { t-критерій } \\
\text { Стьюдента } \\
\text { для } \\
\text { непов'язаних } \\
\text { сукупностей }\end{array}$} & \multirow{2}{*}{$\begin{array}{l}\text { Відношення } \\
\text { шансів } \\
\text { (OR) }\end{array}$} \\
\hline & & $\begin{array}{l}\text { абс. } \\
\text { число }\end{array}$ & $\%$ & $\begin{array}{c}\text { аббс. } \\
\text { число }\end{array}$ & $\%$ & & \\
\hline \multicolumn{8}{|c|}{ A } \\
\hline 1. & $\begin{array}{l}\text { У вашому класі прийнято } \\
\text { битися }\end{array}$ & 5 & 14,3 & 2 & 6,25 & 21,21 & 0,4000 \\
\hline 2. & $\begin{array}{l}\text { Коли в школі відбувається } \\
\text { бійка, ви не звертаєте уваги, } \\
\text { це звичайна справа }\end{array}$ & 9 & 25,7 & 22 & 68,8 & 91,92 & 6,356 \\
\hline 3. & $\begin{array}{l}\text { Якщо хтось починає кричати, } \\
\text { або битися, або клас «встає на } \\
\text { вуха», це припиниться, коли } \\
\text { всі втомляться }\end{array}$ & 10 & 28,6 & 15 & 46,9 & 35,36 & 2,206 \\
\hline 4. & $\begin{array}{l}\text { У школі вам в цілому не } \\
\text { подобається, погано, ніхто ні } \\
\text { з ким не дружить }\end{array}$ & 0 & 0 & 10 & 31,3 & 70,71 & - \\
\hline 5. & $\begin{array}{l}\text { Коли ваш клас їде кудись, ви } \\
\text { намагаєтеся не їздити }\end{array}$ & 2 & 5,71 & 9 & 28,1 & 49,50 & 6,457 \\
\hline \multicolumn{8}{|c|}{, } \\
\hline 6. & $\begin{array}{l}\text { У вашому класі прийнято } \\
\text { разом розважатися після } \\
\text { уроків }\end{array}$ & 6 & 17,1 & 18 & 56,3 & 84,85 & 6,214 \\
\hline 7. & $\begin{array}{l}\text { У вашому класі прийнято } \\
\text { ходити один до одного в гості }\end{array}$ & 11 & 31,4 & 20 & 62,5 & 63,64 & 1,983 \\
\hline 8. & $\begin{array}{l}\text { У вашому класі прийнято } \\
\text { заступатися за своїх }\end{array}$ & 3 & 8,6 & 14 & 43,8 & 77,78 & 8,296 \\
\hline 9. & $\begin{array}{l}\text { У школі вам в цілому } \\
\text { подобається, приємно, цікаво }\end{array}$ & 0 & 0 & 10 & 31,3 & 70,71 & - \\
\hline 10. & $\begin{array}{l}\text { Коли ваш клас їде кудись, } \\
\text { вам це подобається, це весело }\end{array}$ & 2 & 5,71 & 12 & 37,5 & 70,71 & 9,900 \\
\hline
\end{tabular}




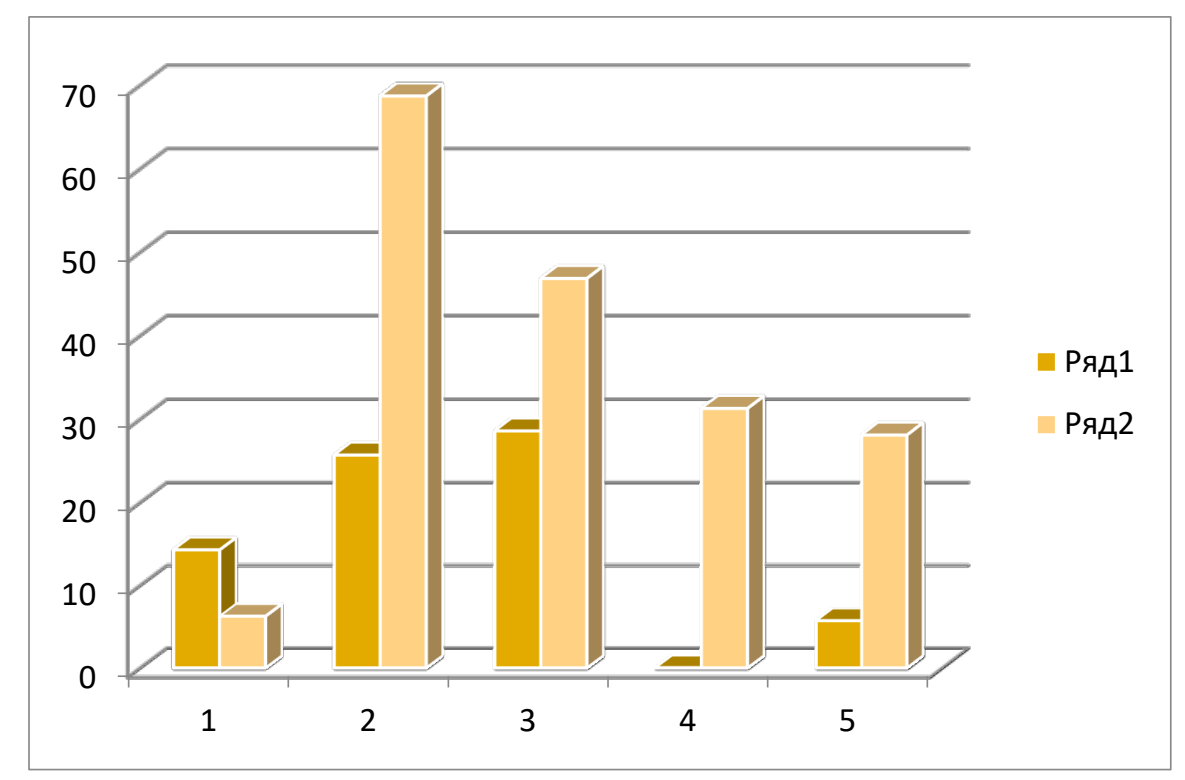

$\mathrm{a}$

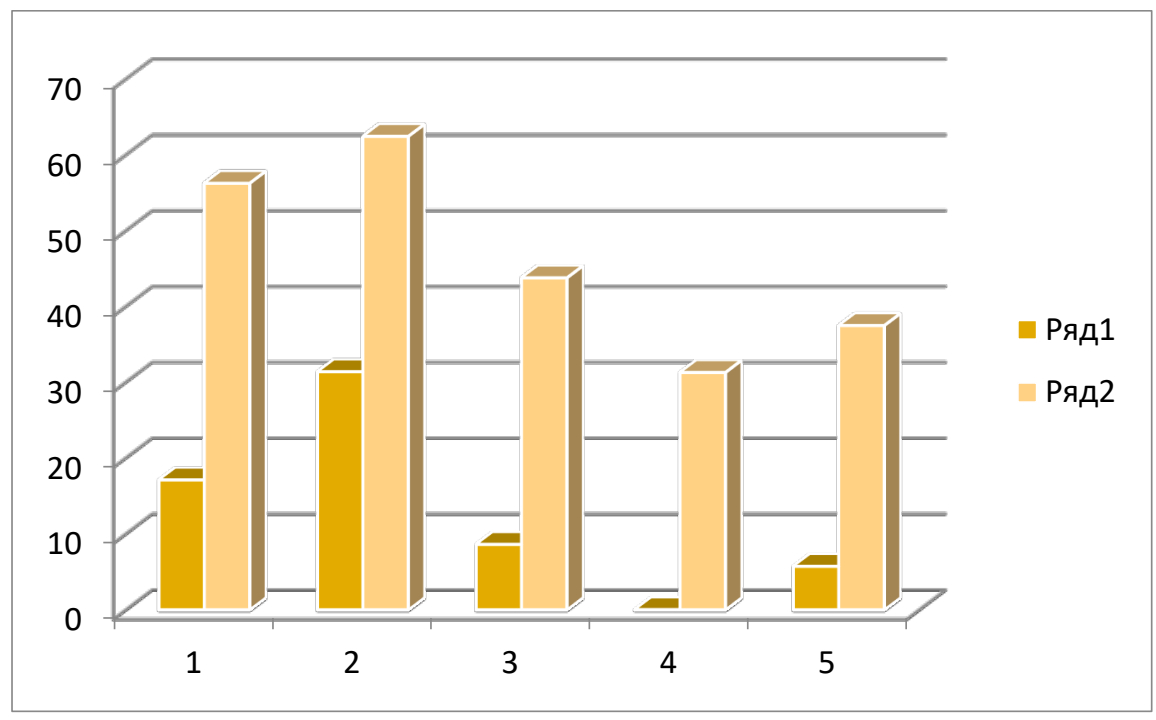

6

Рис. 9. Порівняння класів за шкалою роз’єднаності (а - відповіді «ТАК», б відповіді «НІ»; ряд 1 - 7-Б, ряд 2 - 7-В класи)

Як добре видно з рисунку, ризик булінгу за шкалою роз'єднаності в 7-В класі є значно вищим, ніж у 7-Б класі. Різниця показників між класами є статистично значимою, що відображено в таблиці. Відсутність згуртованості і взаємодопомоги збільшують шанси виникнення булінгу в 7-В класі.

До шкали рівноправності входять 11 питань (максимальна кількість балів 11), за кожну позитивну відповідь на будь-яке 3 цих питань зараховується бал (таблиця 7., рис.10.). 
Таблиця 7.

Порівняння досліджуваних класів за шкалою рівноправності

\begin{tabular}{|c|c|c|c|c|c|c|c|}
\hline \multirow{2}{*}{$\begin{array}{l}\text { № } \\
\text { 3/ח }\end{array}$} & \multirow{2}{*}{ Запитання } & \multicolumn{2}{|l|}{ 7-5 } & \multicolumn{2}{|l|}{ 7-B } & \multirow{2}{*}{$\begin{array}{l}\text { t-критерій } \\
\text { Стьюдента } \\
\text { для } \\
\text { непов'язаних } \\
\text { сукупностей }\end{array}$} & \multirow{2}{*}{$\begin{array}{l}\text { Відношення } \\
\text { шансів } \\
(\mathrm{OR})\end{array}$} \\
\hline & & $\begin{array}{c}\text { абс. } \\
\text { число }\end{array}$ & $\%$ & $\begin{array}{l}\text { абс. } \\
\text { число }\end{array}$ & $\%$ & & \\
\hline 1. & $\begin{array}{l}\text { У класі } є \text { хтось кого всі } \\
\text { поважають }\end{array}$ & 27 & 77,1 & 18 & 56,3 & 63,64 & 0,381 \\
\hline 2. & $\begin{array}{l}\text { У класі є хтось кого всі } \\
\text { бояться }\end{array}$ & 7 & 20,0 & 12 & 37,5 & 35,36 & 2,400 \\
\hline 3. & $\begin{array}{l}\text { У класі є хтось на кого } \\
\text { хочеться бути схожим }\end{array}$ & 16 & 45,7 & 10 & 31,3 & 42,43 & 0,511 \\
\hline 4. & $\begin{array}{l}\text { У класі } є \text { хтось } 3 \text { ким краще } \\
\text { не сперечатися }\end{array}$ & 14 & 40,0 & 17 & 53,1 & 21,21 & 1,700 \\
\hline 5. & $\begin{array}{l}\text { Вчитель в класі звертається } \\
\text { до учнів по імені та по } \\
\text { батькові }\end{array}$ & 5 & 14,3 & 4 & 12,5 & 7,07 & 0,857 \\
\hline 6. & $\begin{array}{l}\text { Коли в школі відбувається } \\
\text { бійка, ви приєднуєтеся, } \\
\text { вставши на чиюсь сторону }\end{array}$ & 5 & 14,3 & 2 & 6,25 & 21,21 & 0,400 \\
\hline 7. & $\begin{array}{l}\text { Коли в школі відбувається } \\
\text { бійка, ви багато це потім } \\
\text { обговорюєте між собою в } \\
\text { класі }\end{array}$ & 23 & 65,7 & 13 & 40,6 & 70,71 & 0,357 \\
\hline 8. & $\begin{array}{l}\text { Цінні речі можна залишати в } \\
\text { роздягальні }\end{array}$ & 11 & 31,4 & 6 & 18,8 & 35,36 & 0,503 \\
\hline 9. & $\begin{array}{l}\text { Виклик до директора - це } \\
\text { хочуть за щось похвалити }\end{array}$ & 21 & 60,0 & 11 & 34,4 & 70,71 & 0,349 \\
\hline 10. & $\begin{array}{l}\text { Перерву я проводжу, } \\
\text { заходячи к друзям в інші } \\
\text { класи }\end{array}$ & 10 & 28,6 & 8 & 25,0 & 14,14 & 0,833 \\
\hline 11. & $\begin{array}{l}\text { Клас має репутацію } \\
\text { відмінників }\end{array}$ & 6 & 17,1 & 5 & 15,6 & 7,07 & 0,895 \\
\hline
\end{tabular}


За шкалою рівноправності також виявлено статистично значимі відмінності показників 7-Б та 7-В класів, що особливо помітно на рисунку.

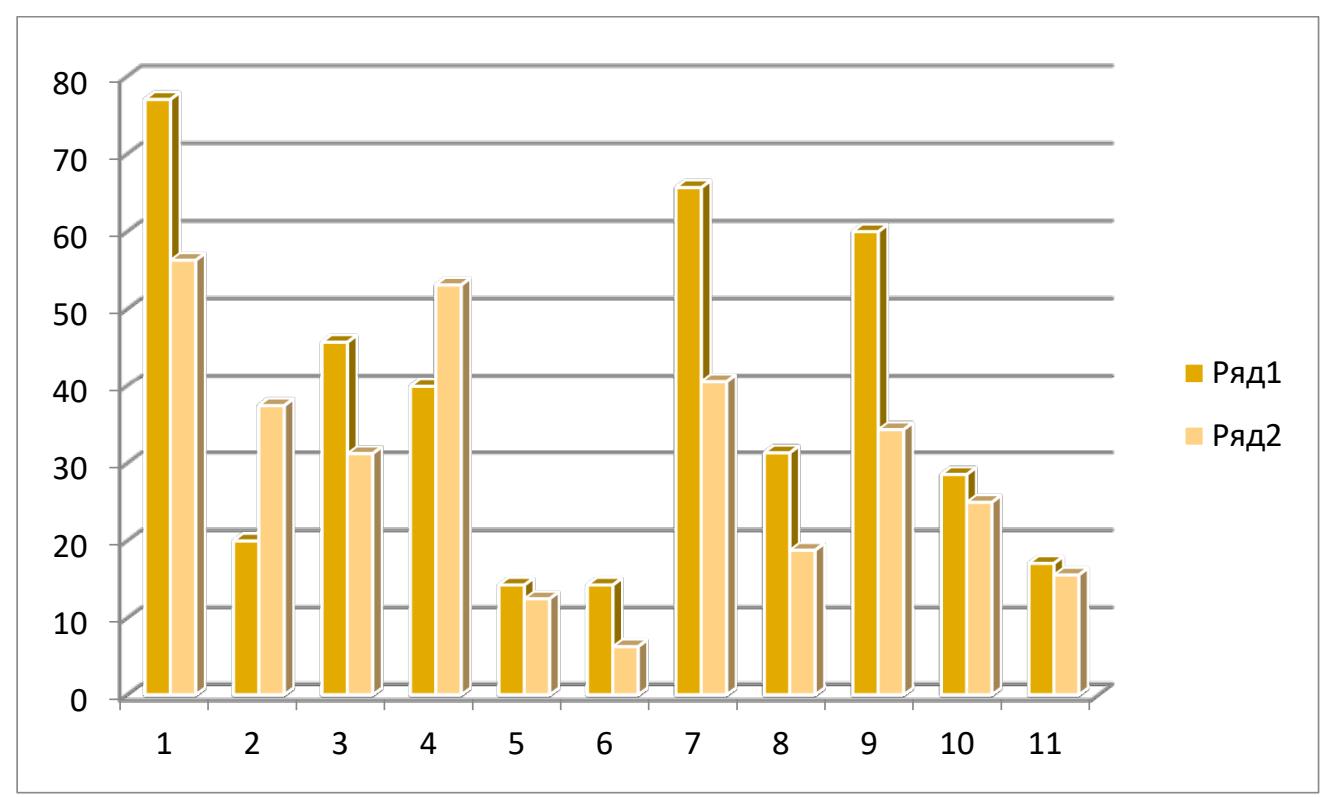

Рис.10. Порівняння показників ризику булінгу в 7-Б та 7-В класах за шкалою рівноправності (ряд 1- 7-Б клас, ряд 2 - 7-В клас)

Втім, показники за даною шкалою, як свідчать статистичні розрахунки, не підвищують істотним чином шанси виникнення булінгу в досліджуваних класах, за виключенням наявності когось, кого всі бояться та 3 ким краще не сперечатися. Слід зауважити, що за іншими шкалами наявність такого агресивного неформального лідера помітно не виявлялася.

Результати підрахунку середніх балів по шкалах ризику булінгу та їх порівняння наведені в таблиці 8.

Таблиця 8.

Порівняльна оцінка ризику булінгу в досліджуваних класах

\begin{tabular}{|c|c|c|c|c|}
\hline Клас & $\begin{array}{l}\text { шкала } \\
\text { небезпеки } \\
(\max =16)\end{array}$ & $\begin{array}{l}\text { шкала } \\
\text { роз'єднаності } \\
(\max =10)\end{array}$ & $\begin{array}{l}\text { шкала } \\
\text { благополуччя } \\
(\max =11)\end{array}$ & $\begin{array}{l}\text { шкала } \\
\text { рівноправності } \\
(\max =11)\end{array}$ \\
\hline 7-Б & 5,11 & 1,37 & 5,65 & 4,29 \\
\hline 7-B & 8,28 & 4,13 & 5,13 & 3,31 \\
\hline $\begin{array}{l}\text { t-критерій } \\
\text { Стьюдента для } \\
\text { непов’язаних } \\
\text { сукупностей } \\
\text { (f=65, } \\
\text { tкритичне=1,998 } \\
\text { при } \alpha=0,05\end{array}$ & 22,42 & 19,52 & 3,68 & 6,93 \\
\hline $\mathrm{P}$ & $<0,05$ & $<0,05$ & $<0,05$ & $<0,05$ \\
\hline
\end{tabular}


Як видно $з$ даної таблиці, загалом показники ризику булінгу по всіх шкалах методики знаходяться приблизно на середньому рівні. Втім, виявлено статистично значиму їх відмінність по всіх шкалах між досліджуваними 7-Б та 7-В класами. При цьому, учні 7-Б класу оцінюють свій клас як більш безпечний і благополучний, ніж учні 7-В класу. Слід звернути увагу на те, що за шкалами небезпеки та роз'єднаності показники 7-В класу вдвічі перевищують такі в 7-Б класі, хоча й не досягають максимальних значень. Водночас, за шкалою благополуччя різниця між класами в показниках є хоча й статистично значимою, але не істотною, а от за шкалою рівноправності показники 7-В класу знову-таки є гіршими, ніж 7-Б класу, хоч і не настільки, як за двома першими шкалами. Таким чином, 3 таблиці можна визначити нерівноправність учнів 7-В класу, що спричиняє їх роз'єднаність і створює відчуття небезпеки. Натомість, учні 7-Б класу є більш рівноправними та згуртованими, мають низький бал за шкалою роз'єднаності, тому й показник за шкалою небезпеки в них майже вдвічі нижчий за такий у 7-В класі (рис.11.).

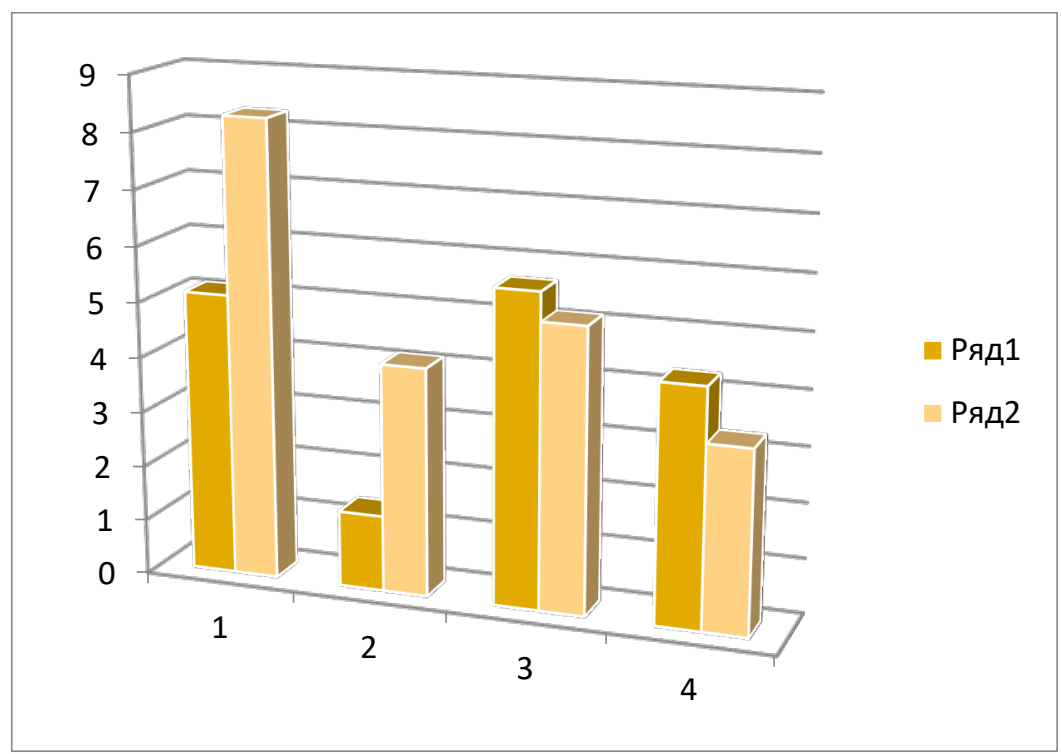

Рис.11. Порівняльна оцінка ризику булінгу в 7-Б (ряд 1) та 7-В (ряд 2) класах (шкали: 1- небезпеки, 2- роз’єднаності, 3- благополуччя, 4 - рівноправності)

Отже, ризик виникнення булінгу в 7-В класі є досить вірогідним, що потребує відповідних психопрофілактичних заходів. Шкільному психологу слід приділити особливу увагу даному колективу, провести більш глибоку 
діагностику, проаналізувати соціометричний статус, спланувати психопрофілактичні заходи, залучивши до цієї роботи як учнів, так і вчителів i батьків. Варто також зауважити, що за шкалою небезпеки дівчинки оцінювали свій клас вище, ніж хлопчики. За шкалою благополуччя дівчинки також оцінюють обстановку вище, ніж хлопчики. Подібна різниця пояснюється відмінностями в розвитку хлопчиків і дівчаток. Поряд 3 біологічними передумовами в розвитку статевих відмінностей серйозну роль грають соціальні і культурні стереотипи. Хлопчики і дівчатка по-різному проявляють агресивність. По-різному до неї відносяться і оцінюють. Відчуття небезпеки і роз'єднаності у хлопчиків помітно вище, ніж у дівчаток. У віці 13 років проявляється невміння організовувати спільну діяльність при основній потребі бути визнаним у своєму колі. Вирішення цієї проблеми в основному залежить від класного керівника або вчителя, який правильно зможе організувати спільну діяльність.

Результати психодіагностичного дослідження учнів 7-Б та 7-В класів за опитувальником В. Р. Петросянц «Ситуація булінгу в школі» показали, що ствердно відповіли на запитання щодо існування проблеми шкільного булінгу 45,7\% учнів 7-Б та аж 71,9\% учнів 7-В класу. Співвідношення ствердних відповідей серед хлопчиків в обох класах було майже однаковим (58,8\% та 60,0\%), а от дівчат, які дали відповідь «ТАК» щодо існування булінгу, в 7-Б класі було значно менше, ніж у 7-В (33,3\% та 82,3\% відповідно). Більшість опитаних дітей джерело булінгу вбачають серед учнів старших класів (34,3\% в 7-Б та 28,1\% в 7-В класах), а також серед однолітків (25,7\% та 46,9\%), деякі називають також учнів молодших класів $(17,1 \%$ та 15,6\%) - майже однакова кількість дітей в обох досліджуваних класах дали ствердну відповідь щодо молодших школярів. А от щодо вчителів, їхнє ставлення назвали причиною булінгу лише 2 хлопчики (по 1 в кожному 3 досліджуваних класів). Водночас, декілька учнів впевнено заперечують наявність булінгу в їхній школі, причому слід звернути увагу, що в більш благополучному 7-Б класі таких 20,0\%, тоді як в 7-В класі, який становить 
більший ризик щодо можливості булінгу, їх лише 6,3\%. Цікаво також, що булінг заперечують 22,2\% відсотки дівчаток та 17,6\% хлопчиків із 7-Б класу, тоді як в 7-В класі заперечили існування булінгу лише 2 хлопчики, тоді як жодна 3 дівчаток цього класу не дала негативної відповіді на це запитання.

В повній безпеці відчувають себе в школі 34,2\% учнів 7-Б класу та лише $28,1 \%$ учнів 7-В класу, і приблизно однакова кількість дітей $(62,9 \%$ та 68,8\% відповідно) в кожному класі вважають, що відчуття безпеки залежить від обставин. Не відчувають себе в безпеці лише 2 дитини - по 1 хлопчику з кожного класу,- ті ж самі, які джерелом булінгу назвали вчителів, що потребує відповідної уваги а психопрофілактично-психокорекційних заходів.

Насильство в школі заперечує приблизно половина учнів кожного класу (51,7\% та 50,0\% відповідно), а от ті ж самі 2 хлопчики вказують на булінг під час уроків, причому щоденний. Отже, ці діти є вразливими, відчувають негативне ставлення з боку вчителів, і становлять ризик булінгу 3 боку як учителів, так і учнів. Раз на тиждень відчувають булінг також 2 дівчинки (по 1 із кожного досліджуваного класу). Переважна більшість дітей стверджують, що насильство не відчували $(71,4 \%$ в 7-Б та $65,6 \%$ - в 7-В класах), інші діти стикаються з проявами булінгу 1-2 рази на місяць. Серед способів булінгу перше місце посідають насмішки та ігнорування. Не втручатися в ситуацію булінгу вважають за краще 22,9\% учнів 7-Б та 21,9\% учнів 7-В класів, однак більшість опитаних дітей все-таки прагнуть допомогти жертві булінгу. Водночас, усі опитані діти переконують, що ніколи не брали участі в булінгу (80,0\% та 75,0\%) або брали раніше, давно, а тепер такого не роблять (20,0\% та 15,0\% відповідно) (рис.12.).

Жоден із учнів з 7-Б або 7-В класів не вказав, що він займається булінгом (анкети були анонімні). 80\% учнів 7-Б класу та 75\% учнів 7-В класу вказали, що ніколи не брали участь в булінгу. 20\% учнів 7-Б класу та 25\% учнів 7-В класу вказали, що раніше брали участь в булінгу, але тепер ні. 


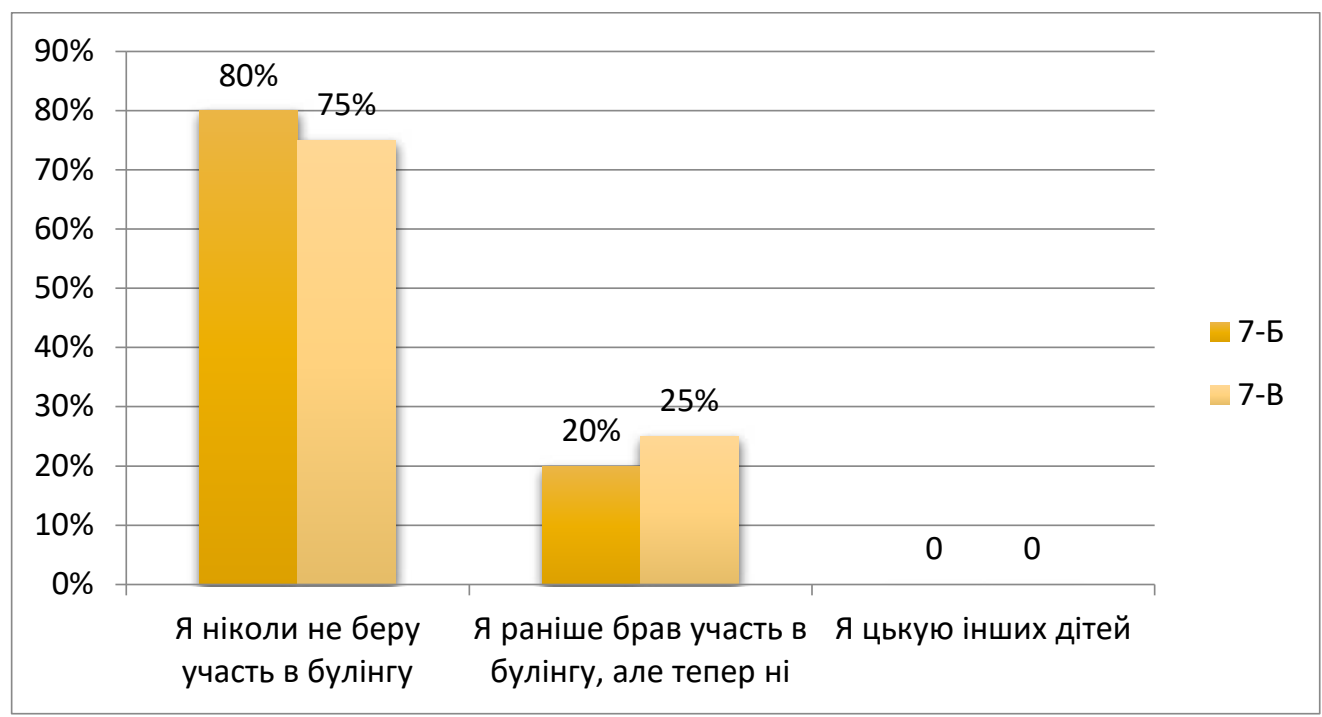

Рис.12. Наявність буллі серед учнів 7-Б (ряд 1) та 7-В (ряд 2) класу

Також більшість учнів вказували, що вони не відчували ні психічного, ні фізичного насилля, але при цьому зазначали один або більше методів булінгу, які інші учні використовували до них. Це може пояснюватися тим, що це були одиночні випадки, які не мали систематичного характеру, що характерно для самого булінгу.

Висновки та перспективи подальших досліджень. Загалом показники ризику булінгу по всіх шкалах методики знаходяться приблизно на середньому рівні по двом класам. Але ризик виникнення булінгу в 7-В класі є більш вірогідним, що потребує відповідних психопрофілактичних заходів. Шкільному психологу слід приділити особливу увагу даному колективу, провести більш глибоку діагностику, проаналізувати соціометричний статус, спланувати психопрофілактичні заходи, залучивши до цієї роботи як учнів, так і вчителів і батьків.

Провідною проблемою діагностики та профілактики булінгу є те, що в українській культурі даний феномен входить в звичайний досвід і мало усвідомлюється, в силу чого його прояви часто перериваються, а наслідки і ефекти залишаються поза фокусом уваги фахівців і учасників цькування.

Експериментальне дослідження 3 діагностики ризику булінгу в шкільному колективі показало наявність дітей - потенційних учасників цькування в кожному класі, що підтверджує актуальність даної теми. 
Дана діагностична методика може застосовуватися для вирішення таких прикладних задач, як виявлення колективів 3 підвищеним ризиком ситуацій цькування і створення безпечної атмосфери в навчальних групах, а також освітня i консультативна робота 3 вчителями i шкільною адміністрацією.

\section{Список використаних джерел}

1. Авер'янов А. І. Буллінг як виклик сучасній школі // Педагогіка, психологія та соціологія / А. І. Авер'янов - 2013. - № 18. - С. 45-50.

2. Баєва I.А. Експертна оцінка стану освітнього середовища на предмет комфортності і безпеки // Психологічна наука і освіта/ I.А. Баєва, Є.Б. Лактіонова.- 2013. -№6.-С.5-8

3. Драгунова Т.В. Вікові та індивідуальні особливості молодших підлітків /Т.В. Драгунова, Д.Б. Ельконін.- М.: Вид-во«Просвіта», 1967. -150 с.

4. Емолаєва М.В. Психологія розвитку: методичний посібник для студентів заочної та дистанційної форми навчання / М.В. Емолаєва. - М.: Видавництво ІПО «МОДЕК», 2006. - 241 с.

5. Ениколопов С.Н. Актуальні проблеми дослідження агресивної поведінки // Прикладна юридична психологія/ 2010а. Т. 2. С. 37-47.

6. Забезпечення психологічної безпеки в навчальному закладі: практичне керівництво / під ред. І. А. Баєва. СПб .: Речь, 2006. 288 с.

7. Кірюхіна А.Б. Психологічна сутність насильства // Закон і право. 2009. №2. C.50-52.

8. Мальцева О.А. Профілактика жорстокості i агресивності в шкільному середовищі і способи іiі подолання [Електронний ресурс].- режим доступу: http://www.academy.edu.by/files/29052013_profilaktika_zhestokosti _i_agressivnosti.pdf (дата звернення: 04.06.2016).

9. Ожіева Е. Н. Буллінг як різновид насильства. Шкільний буллінг. [Електронний ресурс] / Є. М. Ожіева. - Режим доступу: http://www.rusnauka.com/33_NIEK_2008/Psihologia/37294.doc.htm 


\section{References}

1. Aver"yanov, A. I. (2013), "Bulling as a Challenge to the Modern School", Pedahohika, psykholohiya ta sotsiolohiya, vol.18, pp. 45-50.

2. Bayeva, I.A. and Laktionova, Ye.B. (2013), "Expert assessment of the state of the educational environment for the subject of comfort and safety", Psykholohichna nauka i osvita, vol. 6., pp.5-8

3. Drahunova, T.V. and El'konin, D.V. (1867), Vikovi ta indyvidual'ni osoblyvosti molodshykh pidlitkiv [Age and peculiarities of younger teens], Vydvo«Prosvita»,Moscow, Russia.

4. Emolayeva, M.V. (2006), Psykholohiya rozvytku: metodychnyy posibnyk dlya studentiv zaochnoyi ta dystantsiynoyi formy navchannya [Developmental Psychology: a methodological manual for students of distance and distance learning], Vyd.-vo IPO «MODEK», Moscow, Russia.

5. Enykolopov, S.N. (2010), "Actual problems of the study of aggressive behavior", Prykladna yurydychna psykholohiya, vol. 2, pp. 37-47.

6. Bayeva, I.A. (2006), Zabezpechennya psykholohichnoyi bezpeky $v$ navchal'nomu zakladi: praktychne kerivnytstvo [Ensuring psychological safety in an educational institution: practical guidance], Rech', SPb, Russia.

7. Kiryukhina, A.B. (2009), "Psychological essence of violence", Zakon $i$ pravo, vol. 2, pp. 50-52.

8. Malceva, O.A. (2016), Prevention of cruelty and aggression in the school environment and ways to overcome it [Online], available at: http://www.academy. edu.by/files/29052013_profilaktika_zhestokosti_i_agressivnosti.).

9. Ozhieva, E. N. "Bulling as a form of violence. School bouling" [Online], available at: http://www.rusnauka.com/33_NIEK_2008/Psihologia/37294.doc.htm 